\title{
Role of Dorsomedial Striatum Neuronal Ensembles in Incubation of Methamphetamine Craving after Voluntary Abstinence
}

\author{
D.Daniele Caprioli, ${ }^{\circledR}$ Marco Venniro, ${ }^{\star}$ Michelle Zhang, Jennifer M. Bossert, Brandon L. Warren, Bruce T. Hope, \\ and $\odot$ Yavin Shaham \\ Behavioral Neuroscience Research Branch, Intramural Research Program, National Institute on Drug Abuse, National Institutes of Health, Baltimore, \\ Maryland 21224
}

\begin{abstract}
We recently developed a rat model of incubation of methamphetamine craving after choice-based voluntary abstinence. Here, we studied the role of dorsolateral striatum (DLS) and dorsomedial striatum (DMS) in this incubation. We trained rats to selfadminister palatable food pellets $(6 \mathrm{~d}, 6 \mathrm{~h} / \mathrm{d})$ and methamphetamine $(12 \mathrm{~d}, 6 \mathrm{~h} / \mathrm{d})$. We then assessed relapse to methamphetamine seeking under extinction conditions after 1 and 21 abstinence days. Between tests, the rats underwent voluntary abstinence (using a discrete choice procedure between methamphetamine and food; 20 trials/d) for $19 \mathrm{~d}$. We used in situ hybridization to measure the colabeling of the activity marker Fos with Drd1 and Drd2 in DMS and DLS after the tests. Based on the in situ hybridization colabeling results, we tested the causal role of DMS $\mathrm{D}_{1}$ and $\mathrm{D}_{2}$ family receptors, and DMS neuronal ensembles in "incubated" methamphetamine seeking, using selective dopamine receptor antagonists (SCH39166 or raclopride) and the Daun02 chemogenetic inactivation procedure, respectively. Methamphetamine seeking was higher after $21 \mathrm{~d}$ of voluntary abstinence than after $1 \mathrm{~d}$ (incubation of methamphetamine craving). The incubated response was associated with increased Fos expression in DMS but not in DLS; Fos was colabeled with both Drd1 and Drd2. DMS injections of SCH39166 or raclopride selectively decreased methamphetamine seeking after 21 abstinence days. In Fos-lacZ transgenic rats, selective inactivation of relapse test-activated Fos neurons in DMS on abstinence day 18 decreased incubated methamphetamine seeking on day 21. Results demonstrate a role of DMS dopamine $\mathrm{D}_{1}$ and $\mathrm{D}_{2}$ receptors in the incubation of methamphetamine craving after voluntary abstinence and that DMS neuronal ensembles mediate this incubation.
\end{abstract}

Key words: Daun02 inactivation; incubation of drug craving; neuronal ensembles; relapse; self-administration; voluntary abstinence

\section{Significance Statement}

In human addicts, abstinence is often self-imposed and relapse can be triggered by exposure to drug-associated cues that induce drug craving. We recently developed a rat model of incubation of methamphetamine craving after choice-based voluntary abstinence. Here, we used classical pharmacology, in situ hybridization, immunohistochemistry, and the Daun02 inactivation procedure to demonstrate a critical role of dorsomedial striatum neuronal ensembles in this new form of incubation of drug craving.

\section{Introduction}

A fundamental feature of addiction to methamphetamine (Rawson et al., 2004) and other abused drugs (Hunt et al., 1971; Jaffe,

Received Oct. 4, 2016; revised Nov. 23, 2016; accepted Dec. 3, 2016.

Author contributions: D.C., M.V., M.Z., J.M.B., B.L.W., B.T.H., and Y.S. designed research; D.C., M.V., M.Z., J.M.B., B.L.W., B.T.H., and Y.S. performed research; D.C., M.V., M.Z., J.M.B., B.L.W., B.T.H., and Y.S. analyzed data;D.C., M.V., M.Z., J.M.B., B.L.W., B.T.H., and Y.S. wrote the paper.

The research was supported by the Intramural Research Program of the National Institute on Drug Abuse and a Brain \& Behavior Research Foundation (formerly the National Alliance for Research on Schizophrenia and Depression) Distinguished Investigator Grant (to Y.S.).

*D.C. and M.V. are co-first authors.

The authors declare no competing financial interests.
1990) is the high rate of relapse during abstinence. In rats, drug seeking progressively increases after forced abstinence from cocaine (Tran-Nguyen et al., 1998; Grimm et al., 2001), heroin (Shalev et al., 2001), nicotine (Abdolahi et al., 2010), alcohol (Bienkowski et al., 2004), and methamphetamine (Li et al., 2015a) self-administration, a phenomenon termed "incubation of drug craving” (Lu et al., 2004). These studies inspired clinical studies demonstrating the incubation of nicotine (Bedi et al.,

Correspondence should be addressed to either Daniele Caprioli or Yavin Shaham, 251 Bayview Boulevard, Room 04A505, Suite 200, Baltimore, MD 21224. E-mail: daniele.caprioli@uniroma1.it or yavin.shaham@nih.gov. D0I:10.1523/JNEUROSCI.3091-16.2016

Copyright $@ 2017$ the authors $\quad 0270-6474 / 17 / 371014-14 \$ 15.00 / 0$ 
2011), alcohol (Li et al., 2015b), cocaine (Parvaz et al., 2016), and methamphetamine (Wang et al., 2013) craving in humans.

Despite the translational utility of the established rat 'incubation of drug craving' model, from a human relapse perspective, the model's limitation is that the abstinence period is experimenter-imposed or forced (Venniro et al., 2016). In humans, abstinence is often voluntary due to either the adverse consequences of drug use or the presence of alternative rewards (Marlatt, 1996; Epstein and Preston, 2003). Based on these considerations, we recently developed a choice-based rat model of relapse after voluntary abstinence (Caprioli et al., 2015b). In this model, which is based on the seminal studies of Lenoir et al. (2007) and Ahmed et al. (2013), rats with a history of palatable food and methamphetamine self-administration voluntarily abstain from drug self-administration when given a mutually exclusive choice between the two rewards (Caprioli et al., 2015b). In our first study (Caprioli et al., 2015b), we used the model to demonstrate that time-dependent increases in methamphetamine seeking (incubation of methamphetamine craving) reliably occur after voluntary abstinence when the alternative nondrug reward is discontinued.

Here, we began to characterize the mechanisms of incubation of methamphetamine craving after voluntary abstinence by determining the role of dorsolateral striatum (DLS) and dorsomedial striatum (DMS). Studies using animal models of relapse/reinstatement demonstrated a role of these two striatal subregions in relapse to heroin (Bossert et al., 2009), cocaine (Fuchs et al., 2006; Pacchioni et al., 2011), alcohol (Wang et al., 2010), and methamphetamine (Rubio et al., 2015) seeking. Additionally, we recently found that incubation of methamphetamine craving after forced abstinence is associated with increased expression of the activity marker Fos (Morgan and Curran, 1991) in both DLS and DMS, and that blockade of $D_{1}$ family receptors in these subregions decrease "incubated" drug seeking after $30 \mathrm{~d}$ of forced abstinence (Li et al., 2015c).

We first used RNAscope in situ hybridization (ISH; Wang et al., 2012) to determine whether the time-dependent increase in methamphetamine seeking (incubation of methamphetamine craving) after voluntary abstinence is associated with timedependent increases in Fos in dopamine $\mathrm{D}_{1}$ and $\mathrm{D}_{2}$ receptorexpressing cells (Drd1 and Drd2) in DMS and DLS. We found that incubated methamphetamine seeking was associated with increased Fos in DMS but not in DLS, and that Fos was colabeled with both Drd1 and Drd2. Based on these results, we determined the effect of DMS injections of the $\mathrm{D}_{1}$ and $\mathrm{D}_{2}$ family receptor antagonists SCH39166 (Chipkin et al., 1988) and raclopride (Köhler et al., 1985) on incubated methamphetamine seeking.

We next determined a role of activated Fos-expressing neurons in DMS in incubated methamphetamine seeking using the Daun02 inactivation procedure that was developed to determine causal roles of neuronal ensembles in learned behaviors (Koya et al., 2009). In this procedure, selective inhibition of behaviorally relevant activated neuronal ensembles is performed by injecting the prodrug Daun02 into specific brain areas of Fos-lac Z transgenic rats (Kasof et al., 1996) that express $\beta$-galactosidase ( $\beta$-gal; the lac $Z$ gene protein product) in neurons strongly activated during behavior (Cruz et al., 2013). Daun02 is cleaved into daunorubicin by $\beta$-gal expressed in strongly activated neurons. Daunorubicin then intercalates into the DNA and inhibits transcription, leading to cell death through apoptosis (Momparler et al., 1976; Bakina and Farquhar, 1999; Ghosh et al., 2000; Pfarr et al., 2015). This results in selective lesioning of only the most active $\beta$-gal-expressing neurons (Koya et al., 2009). Daunorubicin also inhibits calcium-dependent action potentials in a revers- ible manner (Engeln et al., 2016). Studies using the Daun02 inactivation procedure demonstrated causal roles of neuronal ensembles in different brain areas in context-induced reinstatement of cocaine and heroin seeking (Bossert et al., 2011; Cruz et al., 2014), incubation of heroin and nicotine craving (Fanous et al., 2012; Funk et al., 2016), and alcohol seeking and taking, and withdrawal symptoms (Pfarr et al., 2015; de Guglielmo et al., 2016).

\section{Materials and Methods \\ Subjects}

We used male Sprague Dawley rats ( $n=74$; Charles River Laboratories) and male and female Fos-lac $Z$ transgenic rats $(n=51 ; 7$ males and 44 females; Koya et al., 2009), weighing 175-350 g at the beginning of the experiments. We group housed (two per cage) the rats by sex for 1-3 weeks before surgery and then individually housed them after intravenous surgery. In all experiments, we brought the rats to the selfadministration chambers on the first training day and kept them in these chambers during the self-administration, voluntary abstinence, and relapse test phases. We maintained the rats on a reverse $12 \mathrm{~h}$ light/dark cycle (lights off at 8:00 A.M.). The rats had free access to standard laboratory chow and water throughout the entire experiment. Our procedures followed the guidelines outlined in the National Institutes of Health Guide for the Care and Use of Laboratory Animals (http://grants.nih.gov/grants/ olaw/Guide-for-the-Care-and-Use-of-Laboratory-Animals.pdf). We excluded four Sprague Dawley and eight Fos-lac Z transgenic rats due to catheter problems or poor health.

\section{Surgery}

We anesthetized the rats with isoflurane (5\% induction; $2-3 \%$ maintenance) and injected ketoprofen $(2.5 \mathrm{mg} / \mathrm{kg}$, s.c.; Butler Schein Animal Health) after surgery and the following day to relieve pain and decrease inflammation. We allowed the rats to recover from surgery for 3-4 d.

\section{Intravenous surgery}

We performed the intravenous surgeries before palatable food selfadministration training. We inserted SILASTIC catheters into the jugular vein as described previously (Caprioli et al., 2015b) and placed the distal end of the catheters into the jugular vein; we attached the proximal end to a modified 22 gauge cannula to be placed on the back in the midscapular region. We flushed the catheters daily with sterile saline containing gentamicin ( $4.25 \mathrm{mg} / \mathrm{ml}$; APP Pharmaceuticals) every day during the recovery and training phases.

\section{Intracranial surgery}

In experiment 2 , we performed the intracranial surgery at the same time of the intravenous surgery because we tested the rats after 1 and 21 abstinence days. In experiments 3-4 (Daun02 inactivation), in which we tested the rats only on day 21 , we performed the intracranial surgery on abstinence day 1 after the end of the methamphetamine self-administration training phase. We gave the rats 3-4 d to recover before the voluntary abstinence phase (see below). We implanted bilateral guide cannulae (23 gauge; Plastics One) $1 \mathrm{~mm}$ above the DMS. The Paxinos and Watson (2008) coordinates (nose bar set at $-3.3 \mathrm{~mm}$ ) for DMS were as follows: distance from bregma: anteroposterior, $+1.2 \mathrm{~mm}$; mediolateral, $\pm 2.4 \mathrm{~mm}$ ( $8^{\circ}$ angle); and dorsoventral, $-4.3 \mathrm{~mm}$ (Bossert et al., 2009; Li et al., 2015c). We anchored the cannulas to the skull with jeweler's screws and dental cement.

\section{Drugs}

We received (+)-methamphetamine- $\mathrm{HCl}$ (methamphetamine) from the National Institute on Drug Abuse pharmacy. We chose a unit dose of $0.1 \mathrm{mg} / \mathrm{kg}$ for self-administration training based on our previous studies (Caprioli et al., 2015a,b). In experiment 2 (intracranial injections), we dissolved SCH39166 (Tocris Bioscience) and raclopride (Sigma-Aldrich) in sterile water $(2 \mathrm{mg} / \mathrm{ml})$ and injected the drugs bilaterally into the DMS at doses of $1.0 \mu \mathrm{g} / 0.5 \mu \mathrm{l} / \mathrm{side}$ ( $15 \mathrm{~min}$ pretreatment time). These doses are 
also based on a pilot study in which we found that DMS SCH39166 and raclopride injections had no effect on operant responding for food pellets (data not shown). In experiment 3 and 4 , we dissolved Daun02 (4 $\mu \mathrm{g} / 1.0$ $\mu 1 /$ side; Sequoia Research Products) in vehicle solution containing 5\% DMSO, 6\% Tween-80, and 89\% 0.1 m PBS. We chose the Daun02 concentration based on our previous studies (Koya et al., 2009; Bossert et al., 2011; Cruz et al., 2014; Warren et al., 2016). We injected Daun02 at a higher volume than the dopamine receptor antagonists to ensure reliable inactivation of the activated Fos-positive DMS neurons.

\section{Intracranial injections}

Three days before the intracranial injections (vehicle, SCH39166, raclopride, or Daun02), we habituated rats to the injection procedure. The habituation consisted of three phases ( 3 min each). We first exposed the rats to the injection context (an empty cage containing bedding). The day after, we gently removed the cannula blockers before exposing the rats to the injection context. During the last day of habituation, we gently lowered down the injectors and placed them in the injection context. On the test day, we connected the syringe pump (Harvard Apparatus) to $10 \mu \mathrm{l}$ Hamilton syringes and attached the Hamilton syringes to the 30 gauge injectors via polyethylene-50 tubing; the injectors were extended $1 \mathrm{~mm}$ below the tips of the guide cannulas. In experiment 2 , we injected vehicle (saline), SCH39166, or raclopride over $1 \mathrm{~min}$ and left the injectors in place for an additional $1 \mathrm{~min}$ to allow diffusion. In experiments 3 and 4, we injected vehicle or Daun02 over 2 min and left the injectors in place for 2 additional minutes to allow diffusion.

\section{RNAscope in situ hybridization assay}

We performed RNA ISH for Fos, Drd1, and Drd2 mRNAs as described previously (Li et al., 2015c; Rubio et al., 2015; Warren et al., 2016). Sixty minutes after the beginning of the test session, we briefly anesthetized the rats with isoflurane $(<30 \mathrm{~s})$ and decapitated them. We rapidly extracted and froze their brains for $20 \mathrm{~s}$ in isopentane at $-40^{\circ} \mathrm{C}$. We stored brains at $-80^{\circ} \mathrm{C}$ until use. We then collected dorsal striatum coronal sections $(16 \mu \mathrm{m})$ directly onto Superfrost Plus slides (Fisher Scientific). We used an RNAscope Multiplex Fluorescent Reagent Kit (Advanced Cell Diagnostics) and performed the ISH assay according to the user manual for fresh-frozen tissue and as described previously (Li et al., 2015c; Rubio et al., 2015; Warren et al., 2016). On the first day, we fixed brain slices in $10 \%$ neutral buffered formalin (Fisher Scientific) for $20 \mathrm{~min}$ at $4^{\circ} \mathrm{C}$. We rinsed the slices three times in PBS and dehydrated the slices in 50, 70, 100 , and $100 \%$ ethanol. We stored slices in fresh $100 \%$ ethanol overnight at $-20^{\circ} \mathrm{C}$. On the second day, we first dried the slides at room temperature for $10 \mathrm{~min}$. To limit the spreading of the solutions, we drew a hydrophobic barrier on slides around brain slices.

We then treated the slides with protease solution (pretreatment 4) at room temperature for $20 \mathrm{~min}$ and then washed it off. We then applied target probes for Fos, Drd1, and Drd 2 to the slides and incubated them at $40^{\circ} \mathrm{C}$ for $2 \mathrm{~h}$ in the HybEZ oven. Each RNAscope target probe contains a mixture of $20 \mathrm{ZZ}$ oligonucleotide probes that are bound to the target RNA, as follows: Fos-C3 probe (GenBank accession number NM_022197.2; target nt region, 473-1497); Drd1-C1 probe (GenBank accession number NM_012546.2; target nt region, 104-1053); and Drd2-C2 probe (GenBank accession number NM_012547.1; target nt region, 445-1531). Next, we incubated the slides with preamplifier and amplifier probes (AMP1, $40^{\circ} \mathrm{C}$ for $30 \mathrm{~min}$; $\mathrm{AMP} 2,40^{\circ} \mathrm{C}$ for 15 min; AMP3, $40^{\circ} \mathrm{C}$ for $30 \mathrm{~min}$ ). We then incubated the slides with fluorescently labeled probes by selecting a specific combination of colors associated with each channel, as follows: green (Alexa Fluor $488 \mathrm{~nm}$ ), orange (Alexa Fluor $550 \mathrm{~nm}$ ), and far red (Alexa Fluor 647 $\mathrm{nm}$ ). We used AMP4 Alt4 to detect triplex Fos, Drd1, and Drd2 in far red, green, and red channels. Finally, we incubated sections for $20 \mathrm{~s}$ with DAPI. We washed the slides with one washing buffer two times in between incubations. After air drying the slides, we coverslipped them with a Vectashield fluorescent mounting medium (H-1400; Vector Laboratories). We captured fluorescent images of labeled cells in DMS and DLS using an EXi Aqua camera (QImaging) attached to an AxioImager M. 2 microscope using a $20 \times$ objective (Carl Zeiss Mi- croscopy) and iVision software for Macintosh, version 4.0.15 (Biovision). We performed the image capture and quantification in a blind manner (inter-rater reliability between M.V. and M.Z., $r=0.95, p<$ $0.05)$.

\section{$\mathrm{X}$-gal histochemistry for $\beta$-gal visualization with Fos-lacZ rats}

The X-gal assay is based on our previous studies (Koya et al., 2009; Bossert et al., 2011; Warren et al., 2016). Seventy-five minutes after the behavioral tests, we anesthetized the rats with isoflurane and perfused them transcardially with $\sim 100 \mathrm{ml}$ of $0.1 \mathrm{M}$ PBS, pH 7.4, followed by $\sim 400$ $\mathrm{ml}$ of $4 \%$ paraformaldehyde in PBS. We removed the brains and postfixed them in $4 \%$ paraformaldehyde for $2 \mathrm{~h}$ before transferring them to $30 \%$ sucrose in PBS for $48 \mathrm{~h}$ at $4^{\circ} \mathrm{C}$. We froze the brains in dry ice and stored them at $-80^{\circ} \mathrm{C}$. We collected coronal brain sections $(40 \mu \mathrm{m})$ at approximately $+1.2 \mathrm{~mm}$ from bregma (Paxinos and Watson, 2008) in cryoprotectant (20\% glycerol and $2 \%$ DMSO in $0.1 \mathrm{M} \mathrm{PBS}, \mathrm{pH} 7.4)$ and stored them at $-80^{\circ} \mathrm{C}$ until further processing (X-gal labeling). We washed free-floating sections three times for $10 \mathrm{~min}$ each in PBS and incubated them in reaction buffer $(0.1 \mathrm{M} \mathrm{X}$-gal, $100 \mathrm{~mm}$ sodium phosphate, $100 \mathrm{~mm}$ sodium chloride, 5 mм EGTA, 2 mм MgCl2, $0.2 \%$ Triton $\mathrm{X}-100,0.05 \mathrm{M} \mathrm{K} 3 \mathrm{FeCN} 6$, and $0.05 \mathrm{M} \mathrm{K} 4 \mathrm{FeCN} 6$ ) for $5 \mathrm{~h}$ at $37^{\circ} \mathrm{C}$ with gentle shaking. We washed the sections three times for $10 \mathrm{~min}$ each in PBS and mounted them onto chrom-alum/gelatin-coated slides and air dried. We dehydrated the slides through a graded series of alcohol (30\%, 60\%, $90 \%$, $95 \%, 100 \%$, and $100 \%$ ethanol), cleared them with Citrasolv, and coverslipped the slides with Permount. We captured bright-field images of DMS and DLS with a QImaging Exi Aqua camera attached to a Zeiss Axioskop 2 light microscope using a $5 \times$ objective. We counted $\beta$-galexpressing nuclei, characterized by blue nuclear staining, using iVision software for Macintosh, version 4.0.15 (BioVision). We counted nuclei in sampling areas around the DMS injection site (left and right hemispheres) in four coronal sections per rat. We performed the image capture and quantification in a blind manner (inter-rater reliability between D.C. and B.L.W., $r=0.98, p<0.05)$.

\section{Immunofluorescence double-labeling histochemistry for Fos plus $\beta$-gal and for Fos plus NeuN}

We double-labeled $\beta$-gal with Fos and NeuN with Fos using fluorescent immunohistochemistry in four Fos-lac Z rats from the vehicle groups. We rinsed the sections three times with PBS, incubated them for $2 \mathrm{~h}$ in blocking buffer containing 3\% bovine serum albumin, and 5\% normal goat serum in PBS with $0.25 \%$ Triton X-100. We then incubated all sections for at least $24 \mathrm{~h}$ at $4^{\circ} \mathrm{C}$ in anti-Fos primary antibody (1:500; Phospho-Fos, catalog \#5348S, Cell Signaling Technology; RRID: AB_10557109) and either mouse anti- $\beta$-gal (1:1000; catalog \#sc65670, lot \#A2611, Santa Cruz Biotechnology; RRID: AB_831022) or mouse anti-NeuN primary antibody (1:2000 dilution of MAB377, lot \#LV1573084, Millipore; RRID: AB_2298772). Next, we rinsed the sections three times with PBS and incubated them with donkey anti-rabbit Alexa Fluor 488 (1:500; catalog \#A21206, lot \#1480470, Invitrogen; RRID: AB_141708), and goat anti-mouse Alexa Fluor 568 (1:500; catalog \#A11004; lot \#1419715, Invitrogen; RRID: AB_141371) for $2 \mathrm{~h}$, followed by three rinses in PBS. We then mounted the sections on chromalumgelatin-coated slides and coverslipped them with Vectashield HardSet Antifade Mounting Medium (catalog \#H-1400, Vector Laboratories). We captured fluorescent images of labeled cells using an EXi Aqua Camera (QImaging) attached to an AxioImager M.2 Microscope using a 20X objective (Carl Zeiss Microscopy) and iVision software for Macintosh, version 4.0.15 (BioVision). We quantified Fos-immunoreactive cells, $\beta$-gal-immunoreactive cells, or NeuN-immunoreactive cells, and calculated the percentage of colabeled cells from four sections using ImageJ (four images per rat) in a blind manner.

\section{Apparatus}

We trained rats in self-administration chambers as described previously (Caprioli et al., 2015a,b). Briefly, we equipped each chamber with a stainless steel grid floor and two operant panels. We equipped the left panel of 
the chamber with a discriminative stimulus (red light) that signaled the insertion and subsequent availability of the methamphetamine-paired active (retractable) lever. We equipped the right panel of the chamber with a discriminative stimulus (white house light) that signaled the insertion and subsequent availability of the food-paired active (retractable) lever. We equipped the right wall with an inactive (stationary) lever that had no reinforced consequences. We placed a bottle of water and a food hopper on the side of the transparent polycarbonate door of the chamber.

\section{Procedures}

Food pellet self-administration. Our training procedure is similar to that described in our previous studies (Caprioli et al., 2015a,b). We trained the rats to lever press for food during six $1 \mathrm{~h}$ daily sessions that were separated by 10 min under a fixed-ratio-1 (FR1), 20 s timeout reinforcement schedule, which led to the delivery of five $45 \mathrm{mg}$ "preferred" or palatable food pellets ( $12.7 \%$ fat, $66.7 \%$ carbohydrate, and $20.6 \%$ protein; catalog \#1811155, TestDiet); pellet deliveries were paired with the $20 \mathrm{~s}$ discrete tone cue. Before the first one to two formal operant training sessions, we gave the rats a $1 \mathrm{~h}$ magazine training sessions during which five pellets were delivered noncontingently every $5 \mathrm{~min}$. The sessions began with the presentation of the white house light followed 10 s later by the insertion of the food-paired active lever; the white house light remained on for the duration of the session and served as a discriminative stimulus for the palatable food. At the end of the session, the white light was turned off and the active lever was retracted. We used this preferred TestDiet pellet type in our previous studies (Cifani et al., 2012; Calu et al., 2014; Caprioli et al., 2015a,b). To match the number of discrete cue presentations to that of methamphetamine (see below), we limited the number of pellet deliveries to $15 / \mathrm{h}$.

Methamphetamine self-administration. Our methamphetamine selfadministration training procedure is like the one used for food. We trained the rats to self-administer methamphetamine during six $1 \mathrm{~h}$ daily sessions that were separated by 10 min under an FR1 20 s timeout reinforcement schedule; drug infusions were paired with the $20 \mathrm{~s}$ discrete white light cue. The sessions began with the presentation of the red light for $10 \mathrm{~s}$ followed by the insertion of the drug-paired active lever; the red light remained on for the duration of the session and served as a discriminative stimulus for drug availability. At the end of each $1 \mathrm{~h}$ session, the red light was turned off, and the active lever was retracted. The rats self-administered methamphetamine at a dose of $0.1 \mathrm{mg} / \mathrm{kg} /$ infusion over $3.5 \mathrm{~s}$ ( $0.1 \mathrm{ml} /$ infusion). To prevent overdose, we limited the number of infusions to $15 / \mathrm{h}$.

Discrete trials choice procedure. We conducted the discrete choice sessions using the same parameters (dose of methamphetamine, number of palatable food pellets per reward, stimuli associated with the two retractable levers) that we used during the training phase. We allowed rats to choose between the drug-paired and the palatable food-paired lever in a discrete trials choice procedure. We divided each $200 \mathrm{~min}$ choice sessions into 20 discrete trials that were separated by $10 \mathrm{~min}$ as previously described (Lenoir et al., 2007; Caprioli et al., 2015a,b; Vandaele et al., 2016). Briefly, each trial began with the presentation of both discriminative stimuli previously associated with palatable food or drug followed $10 \mathrm{~s}$ later by the insertion of both the palatable food-paired and drug-paired levers. Rats then had to select one of two levers. If the rats responded within $8 \mathrm{~min}$, they received the reward corresponding with the selected lever. Reward delivery was signaled by the drug-associated or foodassociated cue (white cue light or tone, respectively), the retraction of both levers, and turning off the food and methamphetamine discriminative cues. If the rat failed to respond on either active lever within $8 \mathrm{~min}$, both levers were retracted and their associated discriminative cues were turned off with no reward delivery. We introduced three choice sessions during the training phase to assess whether the choice behavior of the rats changes over time during this phase.

Abstinence phase. After completing the training phase, we allowed the rats to choose between the drug- and food-paired levers (delivering five pellets) during 20 discrete choice trials for 19 sessions in experiments 1 and 2 and 14 sessions in experiments 3 and 4 .
Relapse tests. The relapse tests were performed under extinction conditions in the presence of drug-associated or food-associated cues consisted of 60 min sessions on abstinence day 1 or abstinence day 21 (experiments 1 and 2) or 90 min sessions on abstinence day 21 (experiments 3 and 4). The session began with the presentation of the red discriminative cue light (experiments 1-3) or a white light (experiment 4) followed $10 \mathrm{~s}$ later by the insertion of the methamphetamine-paired lever (experiments 1-3) or the food-paired lever (experiment 4); the red or white light remained on for the duration of the session. Active lever presses during testing, the operational measure of drug or food seeking in incubation of drug craving studies (Pickens et al., 2011; Venniro et al., 2016), resulted in contingent presentations of the light cue (experiments $1-3$ ) or the tone (experiment 4) previously paired with drug or food delivery, respectively, but not drug or food delivery.

\section{Specific experiments}

\section{Experiment 1}

Effect of methamphetamine seeking on abstinence days 1 or 21 on Fos expression in DLS and DMS. In experiment 1, we determined whether incubation of methamphetamine craving is associated with increased neuronal activity, as assessed by the activity marker Fos (Curran and Morgan, 1995) in DLS and DMS. We also determined the cell type of the Fos-positive neurons in the two subregions by colabeling Fos with Drd1 and $D r d 2$ receptors. We used four groups of rats ( $n=3-5$ /group) in an experimental design that included the between-subjects factors of test condition (no test, relapse test) and abstinence day (days 1 and 21). The experiment consisted of the following three phases: training phase, discrete choice voluntary abstinence phase, and relapse tests.

Training. We first trained rats to self-administer palatable food pellets (six sessions, $6 \mathrm{~h} /$ session; five pellets/reward delivery) and then trained them to self-administer methamphetamine (12 sessions, $6 \mathrm{~h} / \mathrm{session}$; $0.1 \mathrm{mg} / \mathrm{kg} /$ infusion).

Discrete choice voluntary abstinence. We determined food versus methamphetamine choice after every three consecutive drug selfadministration sessions in all groups (three choice tests) and for $19 \mathrm{~d}$ (voluntary abstinence) preceding the abstinence day 21 relapse test.

Relapse tests. We tested the rats for methamphetamine seeking under extinction conditions on abstinence days 1 and 21. Immediately after the 60 min relapse tests, we anesthetized the rats and processed their brains for the RNAscope in situ hybridization assay. For the no-test rats, we brought them to the perfusion room from their home cage and perfused them on the same day and time as the relapse test rats. We matched the rats in the different groups for methamphetamine intake during the training phase.

\section{Experiment 2}

Effect of DMS SCH39166 or raclopride injections on incubation of methamphetamine craving. In experiment 1 , we found selective time-dependent increases in Fos expression in DMS, but not in DLS, and that Fos was colabeled with both $D r d 1$ and Drd2. Based on these results, in experiment 2 we determined the causal role of DMS dopamine receptors in the incubation of methamphetamine craving after voluntary abstinence. We used six groups of rats ( $n=9-11 /$ group) in a fully factorial experimental design that included the between-subjects factors of drug condition (vehicle, $1.0 \mu \mathrm{g} /$ side SCH39166, and $1.0 \mu \mathrm{g} /$ side raclopride) and abstinence day (days 1 and 21). The experiment consisted of the following three phases: training phase, discrete choice voluntary abstinence phase, and relapse tests.

Training. The experimental conditions were identical to those described in experiment 1.

Discrete choice voluntary abstinence. The experimental conditions were identical to those described in experiment 1 . We habituated the rats to the injection procedure for $3 \mathrm{~d}$ during this phase.

Relapse tests. We tested rats for methamphetamine seeking under extinction conditions on abstinence days 1 and 21. We injected either the $\mathrm{D}_{1}$ receptor antagonist $\mathrm{SCH} 39166(1.0 \mu \mathrm{g} / 0.5 \mu \mathrm{l} /$ side $)$ or the $\mathrm{D}_{2}$ receptor antagonist raclopride $(1.0 \mu \mathrm{g} / 0.5 \mu \mathrm{l} / \mathrm{side})$ into the DMS and determined its effect on both nonincubated methamphetamine seeking in the relapse test performed on abstinence day 1 and on incubated methamphetamine 
seeking on abstinence day 21 . The length of the test session was $60 \mathrm{~min}$. We matched the rats in the different groups for methamphetamine intake during the training phase.

Finally, to verify that SCH39166 and raclopride at the dose we used in the relapse tests does not nonselectively decrease operant responding, we retrained 19 rats ( $n=6-7 /$ group) after the day 21 testing to lever press for the food pellets for $1 \mathrm{~h} / \mathrm{d}$. After 3 training sessions, we injected the rats with vehicle $(0.5 \mu \mathrm{l} /$ side $), \mathrm{SCH} 39166(1.0 \mu \mathrm{g} / 0.5 \mu \mathrm{l} /$ side $)$, and raclopride $(1.0 \mu \mathrm{g} / 0.5 \mu \mathrm{l} / \mathrm{side}) 10 \mathrm{~min}$ before a test session on day 4 .

\section{Experiment 3}

Effect of Daun02 inactivation of activated DMS neurons on incubation of methamphetamine craving. In this experiment, we used the Daun02 inactivation procedure (Koya et al., 2009; Bossert et al., 2011) to determine whether activated neuronal ensembles in DMS play a causal role in incubated methamphetamine seeking. We used two groups of female rats ( $n=11-14$ /group) in an experimental design that included the betweensubject factor of Daun02 dose ( 0 and $4 \mu \mathrm{g} / 1.0 \mu \mathrm{l} /$ side). We used female rats because in a recent study (Venniro et al., 2017) we found no sex differences in methamphetamine self-administration, choice-based voluntary abstinence, and incubation of methamphetamine craving under conditions identical to those used in the present study. Experiment 3 consisted of the following four phases: training phase, discrete choice test, induction day, and relapse tests.

Training. The training conditions were identical to those of experiments 1 and 2.

Discrete choice. We determined food versus methamphetamine choice after every three consecutive drug self-administration sessions (three choice tests) and for $14 \mathrm{~d}$ (voluntary abstinence) preceding the induction day. There were fewer voluntary abstinence choice sessions in experiment 3 (and experiment 4) than in experiments 1 and 2, because we performed the intracranial surgery on abstinence days 1 and 2 and gave the rats $3-4 \mathrm{~d}$ to recover before starting the choice sessions.

Induction session. On abstinence day 18 , we briefly exposed the rats to the methamphetamine self-administration context and cues associated with methamphetamine injections in a 15 min extinction session to induce Fos in DMS. Next, 75 min after the induction session, a time of strong Fos and $\beta$-gal expression (Koya et al., 2009), we injected the rats with Daun02 (to inhibit the Fos-positive activated neurons) or vehicle. Between the induction day and the relapse test, we left the rats undisturbed in the self-administration chambers except for daily handling.

Relapse test. On test day (abstinence day 21), $3 \mathrm{~d}$ after the induction day, we tested all rats for methamphetamine seeking under extinction conditions for $90 \mathrm{~min}$. Immediately after the test session, we perfused the rats and extracted their brains for a subsequent X-gal histochemistry assay of $\beta$-gal expression in DMS and DLS, and verification of cannula placements.

\section{Experiment 4}

Effect of Daun02 inactivation of activated DMS neurons on food seeking. Based on the results of experiment 3, we hypothesized that the Daun02 manipulation selectively inactivated the activated DMS neurons that mediate incubation of methamphetamine craving, but not neurons that encode other non-drug-related learned associations like the learned associations between the palatable food and cues associated with this food. To test this hypothesis, we used two groups of male and female rats $(n=$ 13 /group) in an experimental design that included the between-subject factor of Daun02 dose $(0,4 \mu \mathrm{g} / 1.0 \mu \mathrm{l} / \mathrm{side})$. Experiment 4 consisted of the following four phases: training phase, discrete choice test, induction day, and food relapse tests. We predicted that the selective inactivation of DMS neurons activated by methamphetamine-associated cues on the induction day would not decrease food seeking during a relapse test session 3 d later.

Training. The training conditions were identical to those of experiments $1-3$.

Discrete choice. The discrete choice conditions were identical to those of experiment 3.

Induction day. The induction day conditions were identical to those of experiment 3 .
Relapse test. On test day (abstinence day 21), $3 \mathrm{~d}$ after the induction day, we tested all rats for food seeking under extinction conditions for 90 min. The test session began with the presentation of the food discriminative cue (white house light) followed 10 s later by the insertion of the food-paired active lever; during testing, lever presses on the food-paired lever led to contingent presentations of the $20 \mathrm{~s}$ discrete tone cue but not the food. Immediately after the test session, we perfused the rats and extracted their brains for a subsequent X-gal histochemistry assay of $\beta$-gal expression in DMS and DLS, and verification of cannula placements.

\section{Statistical analyses}

Behavioral data. We analyzed the data with the statistical program SPSS using the GLM module. For the training phase, we analyzed the data separately for food rewards and drug infusions, using the within-subjects factor of session. For the choice sessions, we analyzed the data with repeated-measures ANOVA, using the within-subjects factors of reward type (food, methamphetamine) and choice session. For the relapse tests in experiment 1 , we used one-way ANCOVA with the between-subjects factor of abstinence day (days 1 and 21). For the relapse tests in experiment 2, the statistical analysis of nonreinforced active lever presses included the between-subjects factors of drug condition (vehicle, SCH39166, raclopride) and abstinence day. We also used a mixed ANOVA to analyze the $60 \mathrm{~min}$ time course for the test on day 21, using the between-subjects factor of drug condition and the within-subjects factor of session minutes (20, 40, and $60 \mathrm{~min}$ ). For experiments 3 and 4, we analyzed active lever-press data using one-way ANCOVA with the between-subjects factor of Daun02 dose $(0,4 \mu \mathrm{g} / 1.0 \mu \mathrm{l} / \mathrm{side})$. For experiments 3 and 4, we also used a mixed ANOVA to analyze the $90 \mathrm{~min}$ time course data for day 21 with the between-subjects factor of Daun02 dose and the within-subjects factor of session minutes (30, 60, and $90 \mathrm{~min}$ ). For all the analyses of the behavioral data of the relapse tests, we used inactive lever presses as a covariate.

RNAscope and immunohistochemistry data. In experiment 1, we analyzed Fos expression with a one-way ANOVA that included the between-subject factor group (no test, day 1 test, day 21 test). For experiment 3 , we analyzed $\beta$-gal labeling with a mixed ANOVA that included the between-subjects factor of Daun02 dose and the withinsubjects factor of dorsal striatum subregion (DMS, DLS). For experiment 4 , we analyzed $\beta$-gal labeling with a one-way ANOVA that included the between-subject factor of Daun02 dose (0 and $4 \mu \mathrm{g} / 1.0$ $\mu l /$ side). Because our multifactorial ANOVAs yielded multiple main and interaction effects, we only report significant effects that are critical for data interpretation. Finally, we followed up on significant main and interaction effects $(p<0.05)$ using Fisher's PLSD post hoc tests.

\section{Results \\ Experiment 1}

Effect of methamphetamine seeking on abstinence days 1 or 21 on Fos expression in DLS and DMS

The time line of experiment 1 is shown in Figure $1 A$.

Food and methamphetamine training. The rats increased their food and methamphetamine intake over sessions (Fig. 1B) and, as in our previous study, extended daily access to methamphetamine led to the escalation of drug intake (Krasnova et al., 2014; Caprioli et al., 2015b). The repeated-measures ANOVA showed a significant effect of session for both food $\left(F_{(5,75)}=4.9, p=0.001\right)$ and methamphetamine $\left(F_{(11,165)}=18.7, p<0.0001\right)$. During the three discrete choice sessions, the rats showed a strong preference for the food that increased over time (Fig. 1C). The statistical analysis showed a significant interaction between reward type and session $\left(F_{(2,30)}=7.3, p=0.003\right)$.

Abstinence phase. During the 3 week abstinence period, the rats showed a strong preference for the food, resulting in either no or minimal (1-2 infusions/d) methamphetamine intake (Fig. $1 D)$. The repeated-measures ANOVA showed a significant main effect of reward type $\left(F_{(1,7)}=158.6, p<0.0001\right)$. 


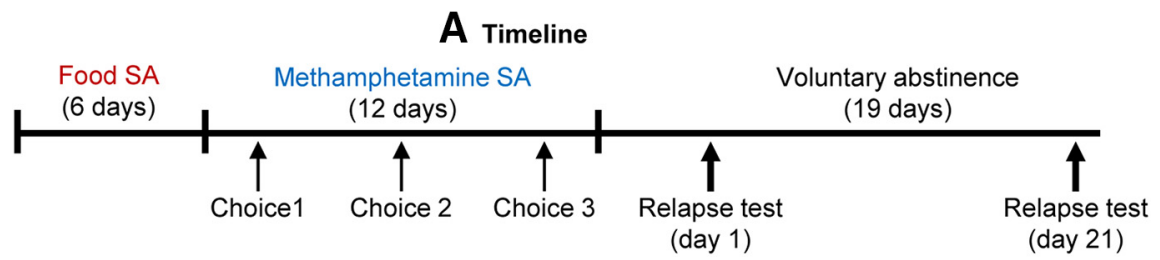

B Self-administration

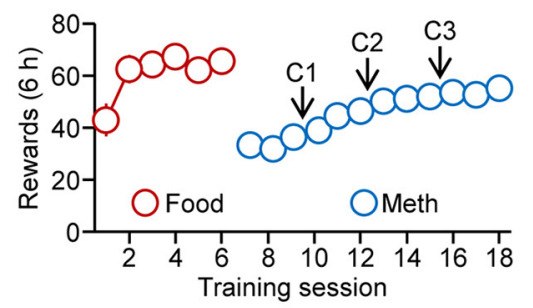

D Voluntary abstinence

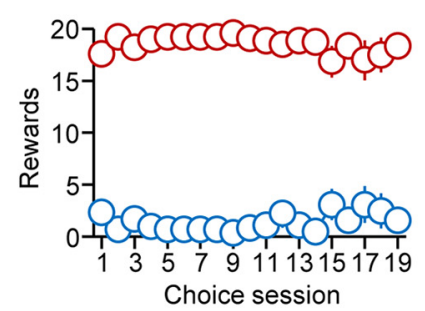

\section{Choice test}

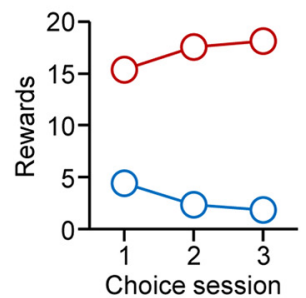

E Relapse test

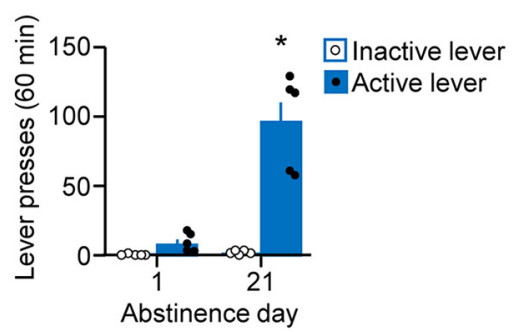

Figure 1. Incubation of methamphetamine (Meth) craving is associated with the activation of DMS, but not of DLS (behavioral data). $\boldsymbol{A}$, Timeline of the experiment. $\boldsymbol{B}$, Food and methamphetamine self-administration (mean \pm SEM number of food rewards; 5 pellets/lever press) and methamphetamine infusions during the $6 \mathrm{~h}$ sessions. C, Discrete choice sessions during training: mean \pm SEM food rewards and methamphetamine infusions earned during the three discrete choice sessions during training. $\boldsymbol{D}$, Voluntary abstinence: mean \pm SEM number of food rewards and methamphetamine infusions earned during the 19 discrete choice sessions. $\boldsymbol{E}$, Relapse tests: mean \pm SEM number of nonreinforced lever presses during the 60 min test sessions. ${ }^{*} p<0.05$ different from day 1. $n=5 /$ group. Circles represent individual data. SA, self-administration.

Relapse tests. Methamphetamine seeking in the relapse tests was higher after 21 abstinence days than after $1 \mathrm{~d}$, demonstrating incubation of methamphetamine craving after voluntary abstinence (Fig. 1E). The statistical analysis, which included the between-subjects factor of abstinence day and inactive lever presses as the covariate, showed a main effect of abstinence day $\left(F_{(1,7)}=27.3, p=0.001\right)$.

Fos and Fos plus Drd1 or Drd2 RNAscope double-label data. Fos expression in the relapse tests was higher after 21 abstinence days than after 1 abstinence day in DMS but not in DLS (Fig. $2 A, B)$. There were no differences in Fos levels in the no-test groups on abstinence days 1 and 21 . Thus, we combined their data to a single no-test group (termed herein no test, $n=6$ ). The statistical analysis, which included the between-subjects factor group (no test, test day 1 , test day 21) showed a significant main effect of this factor for DMS $\left(F_{(2,13)}=7.0, p=0.009\right)$ but not for $\operatorname{DLS}\left(F_{(2,13)}=0.4, p=0.66\right)$. We found no evidence for cell-type specificity of the activated (Fos-positive) DMS neurons on abstinence day $21(48 \pm 9 \%$ and $43 \pm 8 \%$ of the Fos-positive cells coexpressed Drd1 or Drd2, respectively; $9 \pm 2 \%$ of the Fospositive cells did not coexpress Drd1 or Drd2). Representative pictures of Fos/Drd1/Drd2 triple labeling by RNAscope in situ hybridization are shown in Figure 2, $A$ and $B$.

\section{Experiment 2}

Effect of DMS SCH39166 or raclopride injections on incubation of

methamphetamine craving

The time line of experiment 1 is shown in Figure $3 A$.

Food and methamphetamine training. The number of food and methamphetamine rewards earned increased over sessions (Fig. 3B). The repeated-measures ANOVA showed a significant effect of food $\left(F_{(5,285)}=14.9, p<0.0001\right)$ and methamphetamine rewards $\left(F_{(11,616)}=\right.$ $71.2, p<0.0001)$. During the three discrete choice sessions, the rats showed a strong preference for the food that increased over time (Fig. 3C). The statistical analysis showed a significant interaction between reward type and session $\left(F_{(2,114)}=43.1\right.$, $p<0.0001$ ).

Abstinence phase. During the 3 week abstinence period, the rats showed a strong preference for the food, resulting in either no or minimal (1-2 infusions/d) methamphetamine intake (Fig. 3D). The repeated-measures ANOVA showed a significant main effect of reward type $\left(F_{(18,522)}=2.1, p=0.004\right)$.

Relapse tests. DMS injections of SCH39166 and raclopride decreased methamphetamine seeking in the relapse tests on abstinence day 21 but not day 1 (Fig. 3E). The statistical analysis, which included the between-subjects factors of drug condition and abstinence day, and inactive lever-presses as a covariate, showed a significant interaction between abstinence day and drug condition $\left(F_{(2,51)}\right.$ $=3.5, p=0.036)$. We also analyzed the time course of extinction responding on day 21 using the between-subjects factor of drug condition and the within-subjects factor of session minutes $(20,40$, and 60 $\mathrm{min})$. This analysis showed significant effects of significant interaction between drug condition and session time $\left(F_{(4,110)}=3.9\right.$, $p=0.006$; Fig. $3 F)$. Inactive lever presses in the relapse tests were very low (mean \pm SEM of $1.7 \pm 0.3$ and $0.7 \pm 0.1 / 60$ min for day 1 and day 21 tests across the different experimental conditions; data not shown).

Finally, SCH39166 or raclopride at the dose we used in the relapse tests had no effect on operant responding for the food pellets (mean \pm SEM number of active lever presses per $1 \mathrm{~h}$ of $44 \pm 7,51 \pm 5$, and $52 \pm 9$, respectively, for vehicle, SCH39166 ( $1 \mu \mathrm{g} /$ side), and raclopride ( $1 \mu \mathrm{g} /$ side $)$.

\section{Experiment 3}

Effect of Daun02 inactivation of activated DMS neurons on incubation of methamphetamine craving

The time line of experiment 1 is shown in Figure $4 A$.

Food and methamphetamine training. The rats increased their food and methamphetamine intake over sessions (Fig. 4B). The repeated-measures ANOVA showed a significant effect of session for both food $\left(F_{(5,120)}=22.6, p<0.0001\right)$ and methamphetamine $\left(F_{(11,264)}=15.2, p<0.0001\right)$. During the three discrete 
A Fos expression in Drd1 and Drd2 positive cells: DMS (dorsomedial striatum)
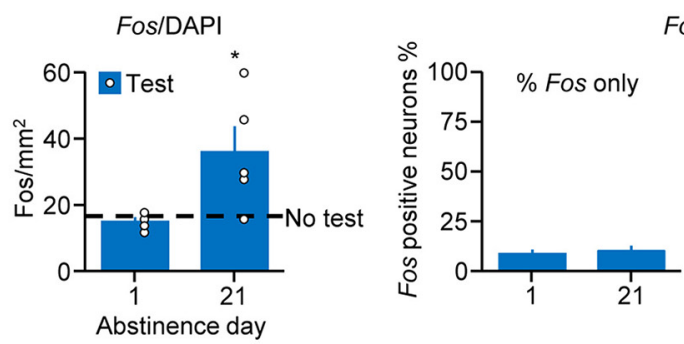

Fos/Drd1/Drd2/DAPI
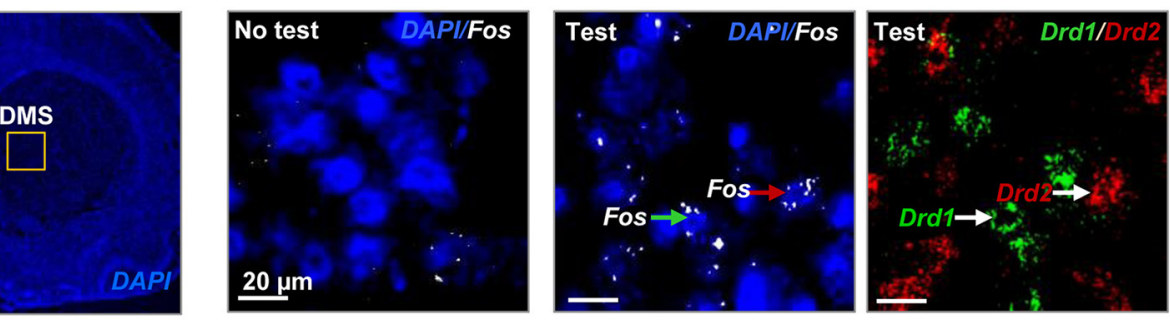

B Fos expression in Drd1 and Drd2 positive cells: DLS (dorsolateral striatum)

Fos/DAPI
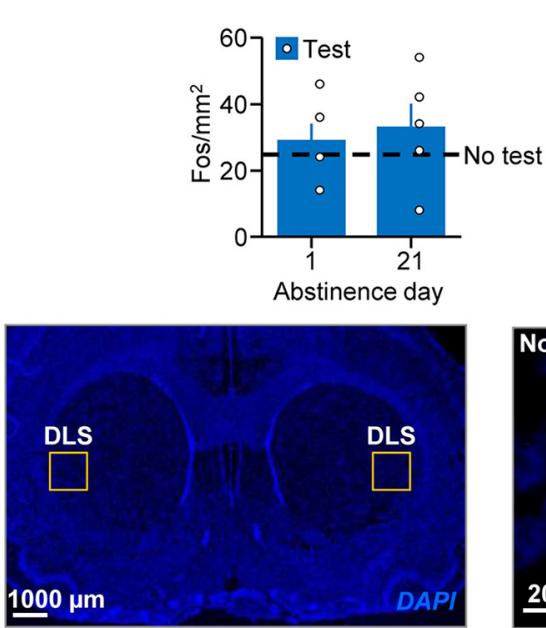

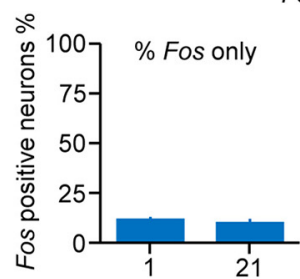

Fos/Drd1/Drd2/DAPI

$$
\% \text { Fos Drd1 } \quad \% \text { Fos Drd2 }
$$

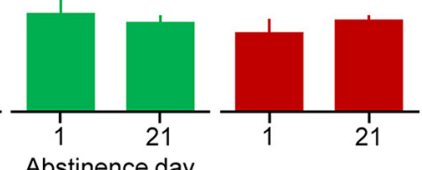

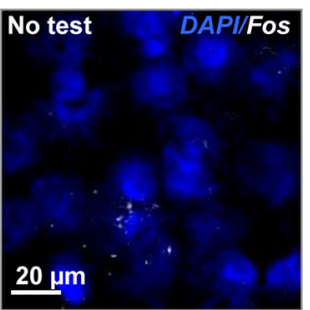
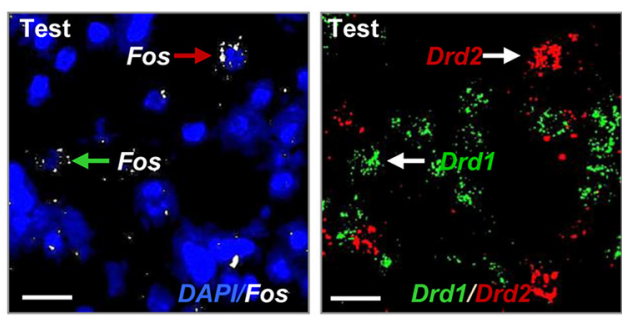

Figure 2. Incubation of methamphetamine craving is associated with the activation of DMS, but not of DLS: RNAscope data. A, Fos expression in Drd1- and Drd2-positive cells: DMS. Left, Fos-positive cells in the DMS in rats that were tested for relapse to methamphetamine seeking on abstinence days 1 and $21\left({ }^{*} p<0.05\right.$, different from day 1$)$. Black dotted line indicates Fos expression level in the no-test control group. Circles represent individual data. Right, Percentages of Fos-positive cells that coexpress Drd $1 \mathrm{mRNA}$ (Drd 1 plus Fos), Drd $2 \mathrm{mRNA}$ (Drd2 plus fos), or neither (Fos alone) in DMS. Bottom panels, Representative images of DMS region (left) and Fos labeling in the no test and relapse test groups (middle), and Drd1 or Drd2 labeling in the relapse test group (right; Fos, white; Drd1, green; Drd2, red; DAPI, blue). Arrows indicate representative cells. B, Fos expression in Drd1-and Drd2-positive cells. Left, DLS Fos-positive cells in the DLS in rats that were not tested or tested for methamphetamine seeking in an relapse test on abstinence days 1 and 21. Black dotted line indicates Fos expression level in the No-test controls. Circles represent individual data. Right, Percentages of Fos-positive cells that coexpress Drd1 (Drd1 plus Fos), Drd2 mRNA (Drd2 plus Fos), or neither (Fos alone) in DLS. Bottom panels, Representative images of DLS region (left; scale bar, $1000 \mu \mathrm{m}$ ) and Fos labeling in both the no-test and relapse test groups (middle; $5 c a l e$ bar, $20 \mu \mathrm{m}$ ), and Drd1 or Drd2 labeling in the relapse test group (right; scale bar, $20 \mu \mathrm{m}$; Fos, white; Drd1, green; Drd2, red; DAPI, blue). Arrows indicate representative cells. $n=5 /$ group for day 1 and day 21 test groups, and $n=6$ for the no-test group (black dashed line).

choice sessions, the rats showed a strong preference for the food (Fig. 4C). The statistical analysis showed a significant main effect of reward type $\left(F_{(1,24)}=136.5, p<0.0001\right)$.

Abstinence phase. During the 3 week abstinence period, the rats showed a strong preference for the food, resulting in either no or minimal (1-2 infusions/d) methamphetamine intake (Fig. $4 D)$. The repeated-measures ANOVA showed a significant main effect of reward type $\left(F_{(1,24)}=659.0, p<0.0001\right)$.

Induction day. On induction day, active lever pressing in the 15 min extinction session was not different between the groups that received vehicle or Daun02 injections 90 min after the onset of the session (mean \pm SEM: vehicle, $28.2 \pm 7.4$ level presses; Daun02, $20.6 \pm 3.7$ level presses; $\left.F_{(1,23)}=1.0, p=0.34\right)$.
Relapse tests. Daun02 inactivation of DMS neurons activated during a short 15 min methamphetamine extinction session (abstinence day 18) decreased methamphetamine seeking $3 \mathrm{~d}$ later (abstinence day 21; Fig. 4E). The statistical analysis of active lever presses, which included the between-subject factor of Daun02 dose and inactive lever presses as a covariate, showed a main effect of Daun02 dose $\left(F_{(1,22)}=10.0, p=0.005\right)$. We also analyzed the time course of active lever pressing during the test session using the betweensubject factor of Daun02 dose and the within-subjects factor of session minutes. This analysis showed a significant interaction between Daun02 dose and session minutes $\left(F_{(2,46)}=13.2, p<0.0001\right)$. These results indicate that Daun 02 decreased the response to the methamphetamine cues during early but not late testing (Fig. $4 F$ ). 


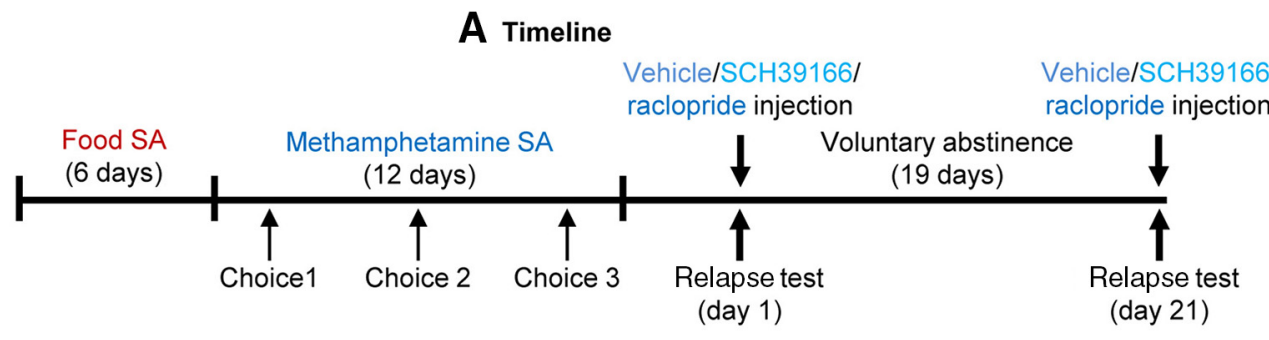

B Self-administration

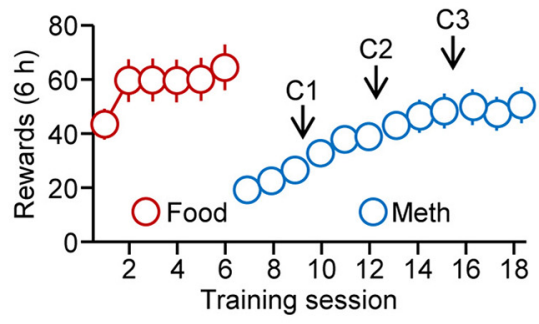

E Relapse test

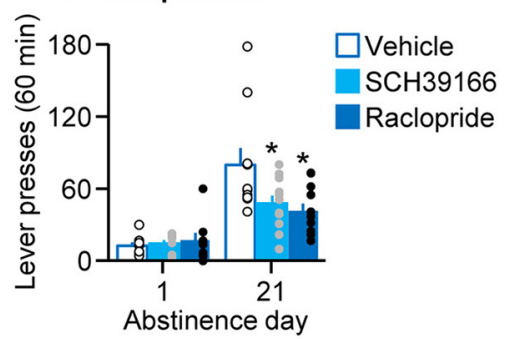

C Choice test

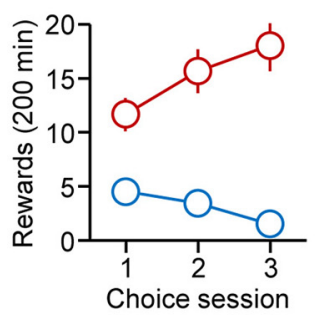

F Time course

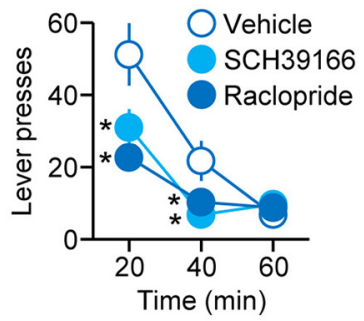

D Voluntary abstinence
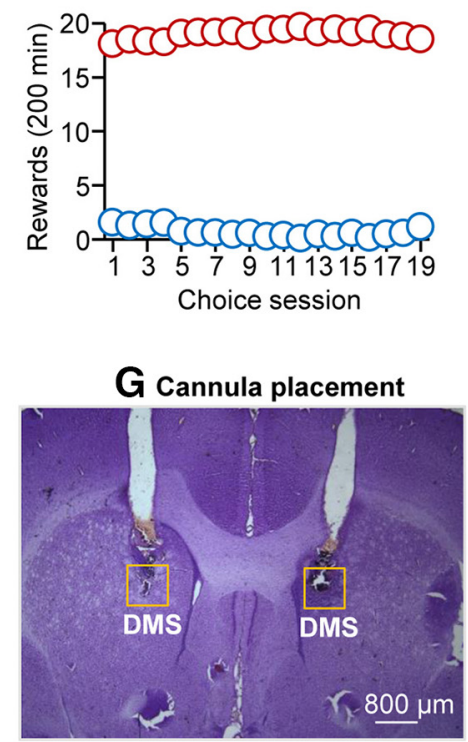

Figure 3. Blockade of DMS $D_{1}$ and $D_{2}$ family receptors decreased incubated methamphetamine seeking after voluntary abstinence. $\boldsymbol{A}$, Timeline of the experiment. $\boldsymbol{B}$, Food and methamphetamine (Meth) self-administration (SA): mean \pm SEM number of food rewards and methamphetamine infusions during the $6 \mathrm{~h}$ sessions. $C$, Discrete choice sessions during training: mean \pm SEM number of food rewards and methamphetamine infusions earned during the three discrete choice sessions during training. $\boldsymbol{D}$, Voluntary abstinence: mean \pm SEM number of food rewards and methamphetamine infusions earned during the 19 discrete choice sessions. $\boldsymbol{E}$, Relapse tests: mean \pm SEM number of nonreinforced lever presses during the $60 \mathrm{~min}$ relapse tests on abstinence days 1 and 21 . *Different from day $1, p<0.05$. $\boldsymbol{F}$, Lever presses on the previously active lever during the 60 min relapse session on day 21 . Circles represent individual data. ${ }^{*}$ Different from vehicle, $p<0.05$. G, Representative photomicrograph of the cannula placement in DMS (scale bar, $800 \mu \mathrm{m}$ ). $n=9$ for day $1 \mathrm{groups}$ and $n=$ $10-11$ for day 21 groups.

$X$-gal histochemistry. Daun02 injections decreased the number of $\beta$-gal-labeled neurons in DMS but not in DLS, which confirmed the successful of inactivation of induction day-activated DMS neurons (Fig. 4H). The statistical analysis that included the between-subjects factors of Daun02 dose and the within-subject factor of dorsal striatum subregion showed a significant interaction between the two factors $\left(F_{(1,23)}=103.6, p<0.0001\right)$. Representative pictures of $\beta$-gal staining are shown in Figure $4 I$.

We also determined Fos plus $\beta$-gal double-labeling in DMS to verify that our Daun02 manipulation targets the Fos-expressing neurons activated during the relapse tests. We found that $79.4 \pm$ $1.1 \%$ of the Fos-positive cells coexpressed $\beta$-gal (Fig. $4 J$ ). This percentage of coexpression is similar to those we observed in our previous studies (Bossert et al., 2011; Fanous et al., 2012; Funk et al., 2016), and the $<100 \%$ coexpression likely reflects differences in the sensitivity of our assay conditions for detecting Fos versus $\beta$-gal. Finally, we determined Fos plus NeuN double-labeling in DMS to determine the approximate proportion of the strongly activated neurons during the late abstinence relapse test. We found that $4.6 \pm 0.36 \%$ of the NeuN-positive cells coexpressed Fos (Fig. $4 K$ ). This percentage of Fos plus NeuN coexpression, reflecting the percentage of neurons strongly activated during the relapse test, is similar to the percentage of Fos plus NeuN coexpression we observed in our previous studies using the Daun02 procedure to study mechanisms of relapse to drug seeking (Bossert et al., 2011; Fanous et al., 2012; Cruz et al., 2014; Funk et al., 2016).

\section{Experiment 4}

Effect of Daun02 inactivation of activated DMS neurons on food seeking

The time line of experiment 1 is shown in Figure 5A.

Food and methamphetamine training. The rats increased their food and methamphetamine intake over sessions (Fig. 5B). The repeated-measures ANOVA showed a significant effect of session for both food $\left(F_{(5,125)}=5.4, p<0.0001\right)$ and methamphetamine $\left(F_{(11,275)}=48.5, p<0.0001\right)$. During the three discrete choice sessions, the rats showed a strong preference for the food (Fig. $5 C)$. The statistical analysis showed a significant interaction between reward type and session $\left(F_{(2,54)}=8.7, p<0.0001\right)$.

Abstinence phase. During the 3 week abstinence period, the rats showed a strong preference for the food, resulting in either no or minimal (1-2 infusions/d) methamphetamine intake (Fig. 


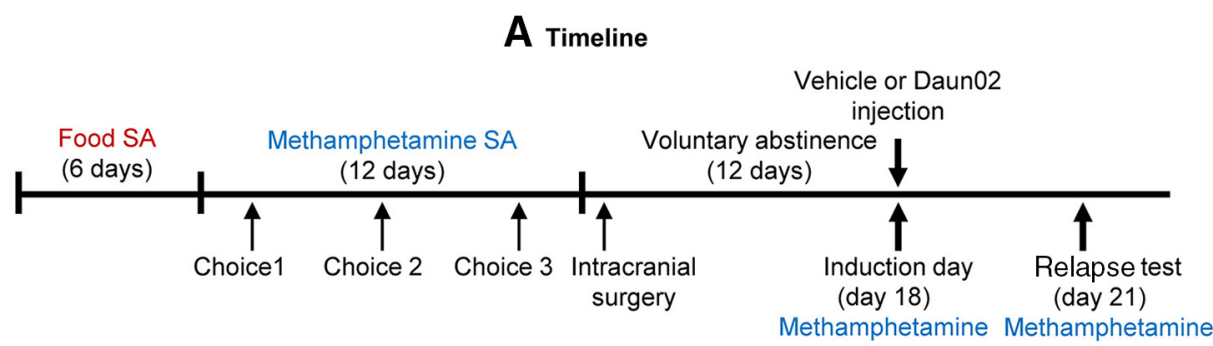

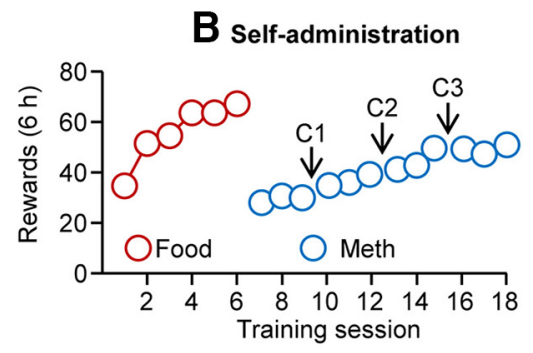

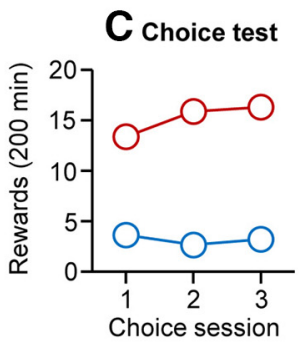

E Relapse test

$F_{\text {Time course }}$
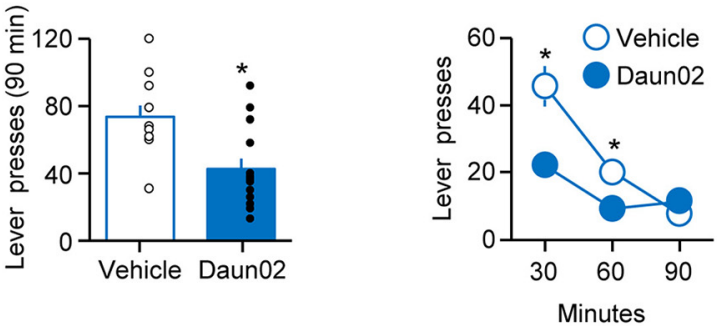

$H_{\beta}$-gal counts DMS
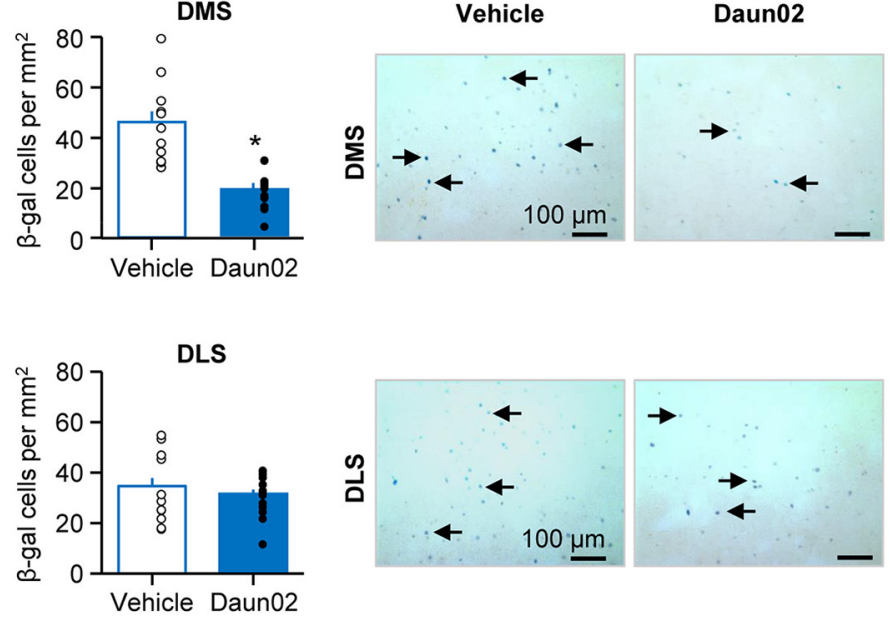

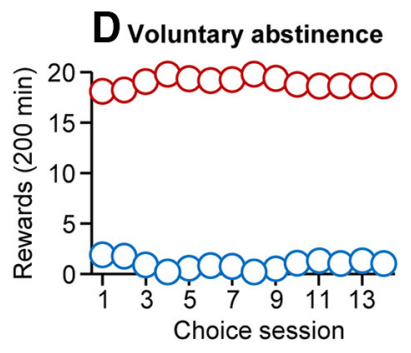

G Cannula placement

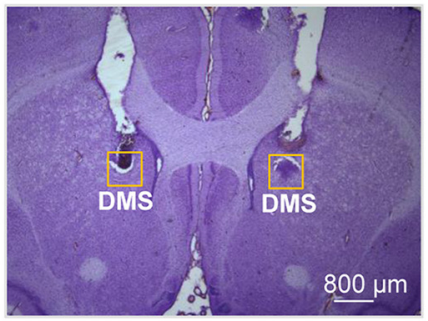

J Fos and $\beta$-gal double-labeling
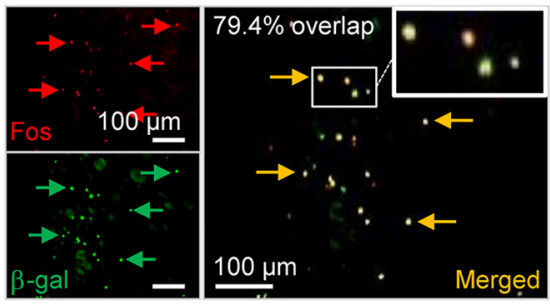

$\mathrm{K}$ Fos and NeuN double-labeling

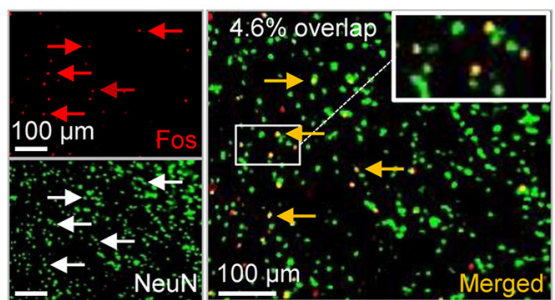

Figure 4. Selective inhibition of methamphetamine (Meth) incubation-related activated DMS neurons with Daun02 decreased incubation of drug craving. $\boldsymbol{A}$, Timeline of the experiment. $\boldsymbol{B}$, Food and methamphetamine self-administration (SA): mean \pm SEM number of food rewards and methamphetamine infusions during the $6 \mathrm{~h}$ sessions. $\boldsymbol{C}$, Discrete choice sessions during training: mean \pm SEM number of food rewards and methamphetamine infusions earned during the three discrete choice sessions during training. $\boldsymbol{D}$, Voluntary abstinence: mean \pm SEM number of food rewards and methamphetamine infusions earned during the 14 discrete choice sessions. $\boldsymbol{E}$, Relapse tests: mean \pm SEM number of nonreinforced presses on the methamphetamine-associated active lever during the 90 min relapse tests on abstinence day 21 . Circles represent individual data. $\boldsymbol{F}$, Time course of the methamphetamine-associated active lever presses during testing. $\mathbf{G}$, Representative photomicrograph of cannula placements in DMS (scale bar, $800 \mu \mathrm{m}$ ). $\boldsymbol{H}, \beta$-Gal-positive cells in the DMS (top) and DLS (bottom) in rats that were tested for relapse to methamphetamine seeking on abstinence day 21. Circles represent individual data. $I$, Representative photomicrograph of $\beta$-gal staining (top, DMS; bottom, DLS). *Different from vehicle, $p<0.05 . n=11-14 /$ group. J, $K$, Fos plus $\beta$-gal and NeuN plus Fos double labeling: representative photomicrographs $(20 \times)$ of Fos plus $\beta$-gal $(\boldsymbol{J})$ or NeuN plus Fos $(\boldsymbol{K})$ in DMS of vehicle-treated Fos-LacZ rats $(n=4)$ that were tested for relapse to methamphetamine seeking on abstinence 21. SA, self-administration. 

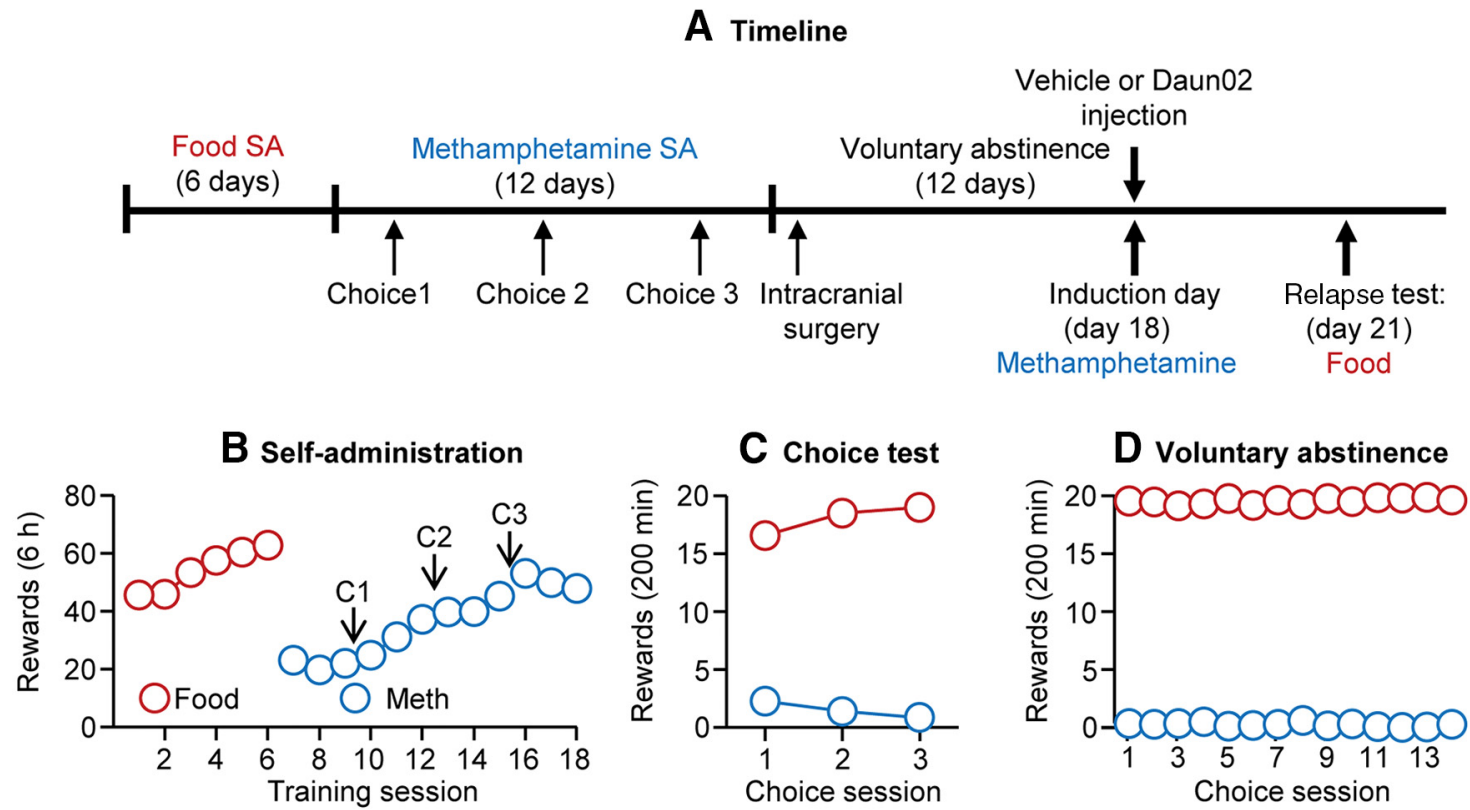

E Relapse test: Food

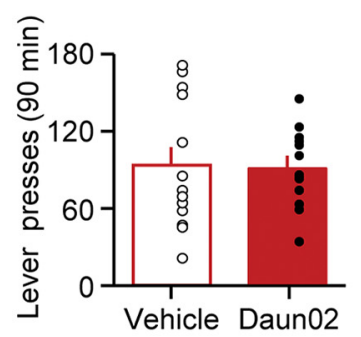

H $\beta$-gal counts

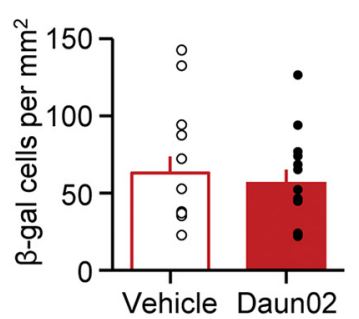

F Time course: Food

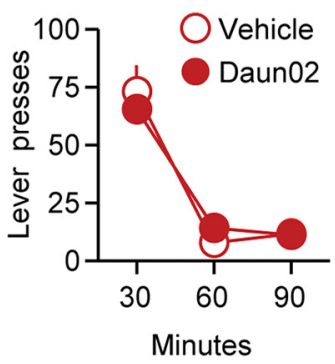

G Cannula placement

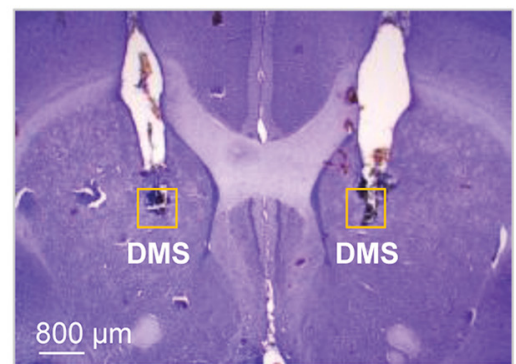

\section{Representative $\beta$-gal staining in DMS}
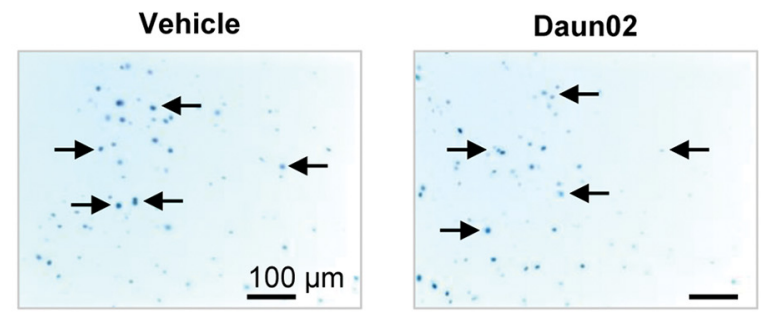

Figure 5. Selective inhibition of methamphetamine (Meth) relapse-encoding DMS neuronal ensembles with Daun02 had no effect on food seeking. $\boldsymbol{A}$, Timeline of the experiment. $\boldsymbol{B}$, Food and methamphetamine self-administration (SA): mean \pm SEM number of food rewards and methamphetamine infusions during the $6 \mathrm{~h}$ sessions. $\boldsymbol{C}$, Discrete choice sessions during training: mean \pm SEM number of food rewards and methamphetamine infusions earned during the three discrete choice sessions during training. $D$, Voluntary abstinence: mean \pm SEM number of food rewards and methamphetamine infusions earned during the 14 discrete choice sessions. $\boldsymbol{E}$, Food relapse tests: mean \pm SEM number of nonreinforced presses on the food-associated active lever during the 90 min test session on abstinence day 21 . Circles represent individual data. $\boldsymbol{F}$, Time course of the food-associated active lever presses. $\boldsymbol{G}$, Representative photomicrograph of cannula placements in DMS (scale bar, $800 \mu \mathrm{m}$ ). $\boldsymbol{H}, \beta$-Gal-positive cells in the DMS in rats that were tested for food seeking on abstinence 21 . Circles represent individual data. I, Representative photomicrograph of $\beta$-gal staining. $n=13$ /group. SA, self-administration.

5D). The repeated-measures ANOVA showed a significant main effect of reward type $\left(F_{(1,25)}=5507.4, p<0.0001\right)$.

Induction day. On induction day, active lever pressing in the 15 min methamphetamine extinction session was not different between the groups that received vehicle or Daun02 injections 90 min after the onset of the session (mean \pm SEM: vehicle, $19.6 \pm$ 4.6 lever presses; Daun02, $17.2 \pm 2.5$ lever presses; $F_{(1,24)}=0.2$, $p=0.65)$.
Relapse tests. Daun02 inactivation of DMS neurons activated during a short 15 min methamphetamine extinction session (abstinence day 18) had no effect on food seeking $3 \mathrm{~d}$ later (Fig. 5E). The statistical analysis of active lever presses during the food relapse session, which included the between-subject factor of Daun02 dose and inactive lever presses as a covariate, showed no effect of Daun02 dose $\left(F_{(1,23)}=0.0, p=0.98\right)$. The analysis of the time course of active lever presses during the food relapse session 
showed a significant effect of session time $\left(F_{(2,48)}=86.2, p<\right.$ $0.0001)$ but no effect of Daun02 dose $\left(F_{(2,48)}=0.0, p=0.91\right)$, or an interaction between the two factors $\left(F_{(2,48)}=1.0, p=0.39\right.$; Fig. $5 F)$.

$X$-gal histochemistry. Daun02 injections on induction day had no effect on the number of $\beta$-gal-labeled neurons in DMS after the $90 \mathrm{~min}$ food relapse session (Fig. $5 H ; F_{(1,24)}=0.2, p=0.65$ for Daun02 effect). Representative pictures of $\beta$-gal staining are shown in Figure $5 I$.

\section{Discussion}

We report three main findings. First, incubated methamphetamine seeking on abstinence day 21 was associated with increased Fos expression in DMS but not DLS; additionally, Fos was coexpressed with both Drd1- and Drd2-expressing neurons. Second, the blockade of DMS $D_{1}$ family and $D_{2}$ family receptors selectively decreased incubated methamphetamine craving after prolonged voluntary abstinence. Most important, Daun02 inactivation of DMS neurons activated during a short relapse session on induction day (abstinence day 18) decreased incubated methamphetamine seeking and DMS neuronal activity $3 \mathrm{~d}$ later during the relapse test on abstinence day 21. In contrast, the same Daun02 inactivation procedure had no effect on food seeking, suggesting that striatal neuronal ensembles controlling incubated methamphetamine seeking do not play a role in food seeking. Together, our results suggest that dopamine transmission through Drd1 and Drd2 in activated DMS neuronal ensembles is critical to the incubation of methamphetamine craving after voluntary abstinence. Finally, as in our previous reports (Caprioli et al., 2015a,b) and the studies of Cantin et al., (2010) and Ahmed et al. (2013), we found that rats will voluntary abstain from extended access psychostimulant self-administration when given a choice between the drug and palatable food.

\section{Methodological considerations}

Several issues should be considered in the interpretation of the present data. One methodological issue could be that the effect of DMS injections of SCH39166, raclopride, or Daun02 on incubated methamphetamine craving are due to nonspecific performance deficits. This is unlikely for SCH39166 and raclopride, because we used a dose that had no effect on operant responding for the palatable food (see Results). As for Daun02 inactivation, this experimental manipulation had a selective effect on methamphetamine but not food seeking during the relapse tests, ruling out a nonselective effect of Daun02 injections.

Another methodological issue could be that in our Daun02 inactivation procedure experiments we primarily used Fos-LacZ female rats, while in the other experiments we used male Sprague Dawley rats. In this regard, several studies demonstrated sex differences in psychostimulant self-administration and relapse (Carroll et al., 2004; Becker and Koob, 2016; Carroll and Lynch, 2016), including the incubation of cocaine craving after forced abstinence (Kerstetter et al., 2008), and cue-induced reinstatement of methamphetamine seeking (Cox et al., 2013). However, it is unlikely that the use of females in the Daun02 experiment confound data interpretation. Specifically, in experiment 4 , in which we used both male and females, we found no evidence for sex differences in methamphetamine self-administration $(n=19$ female, $n=7$ male; $\left.F_{(1,24)}=0.09, p=0.8\right)$ or in the strong preference for the palatable food over methamphetamine during the voluntary abstinence phase $\left(F_{(1,24)}=1.7, p=0.21\right)$. Additionally, in a study using identical experimental conditions, we found no evidence for sex differences in Sprague Dawley rats for methamphetamine self-administration, preference for the palatable food, or the magnitude of incubated methamphetamine seeking after either forced or voluntary abstinence (Venniro et al., 2017).

Finally, from a brain mechanism perspective, a question for future research is the role of DLS dopamine in the incubation of methamphetamine craving after voluntary abstinence. The primary goal of our study was to investigate the neuronal phenotype and the causal role of dorsal striatum Fos-positive neuronal ensembles in the incubation of methamphetamine craving after voluntary abstinence. Therefore, we did not investigate the causal role of DLS in incubated methamphetamine seeking, because we did not observe time-dependent increases in Fos expression after the relapse tests on abstinence days 1 and 21 . However, these correlational data do not rule out a role of DLS in the incubation of methamphetamine craving after voluntary abstinence. In this regard, based on previous studies on the role of DLS dopamine in incubation of methamphetamine after forced abstinence (Li et al., 2015c), cocaine seeking under a second-order reinforcement schedule (Vanderschuren et al., 2005; Belin and Everitt, 2008), and context-induced reinstatement of heroin seeking (Bossert et al., 2009), it is likely that DLS injections of dopamine receptor antagonists will also decrease incubated methamphetamine seeking after voluntary abstinence.

\section{Role of dorsomedial striatum dopamine and neuronal ensembles in incubation of methamphetamine craving}

In two studies published over a decade ago, Ito et al. (2000, 2002) reported that cocaine-seeking behavior under a second-order reinforcement schedule causes a selective increase in dopamine release in the lateral part of the dorsal striatum but not in accumbens core or shell. These seminal studies have led to a series of functional studies in several laboratories that have established a critical role of DLS dopamine transmission and neuronal activity in drug seeking controlled by drug-associated cues and relapse/ reinstatement of drug seeking (Fuchs et al., 2006; Everitt et al., 2008; Belin et al., 2009; Pacchioni et al., 2011; Corbit et al., 2012; Lesscher and Vanderschuren, 2012; Bossert et al., 2013). At present, however, much less is known about the role of DMS dopamine and neuronal activity in drug seeking and relapse.

In the present study we used classical pharmacological methods and the newer Daun02 inactivation procedure (Koya et al., 2009) to demonstrate a critical role of DMS $D_{1}$ and $D_{2}$ family receptors and Fos-expressing neuronal ensembles in relapse to methamphetamine seeking after prolonged voluntary abstinence. These data extend our recent findings showing that the DMS is activated during tests for the incubation of methamphetamine craving after prolonged forced abstinence $(30 \mathrm{~d})$ and that DMS injections of the $\mathrm{D}_{1}$ family receptor antagonist SCH23390 decreases the incubated drug-seeking response (Li et al., 2015c). Unlike this previous study, however, in the present study we did not observe increases in DLS activity (assessed by RNAscope of Fos) during the relapse/incubation tests. These different results for DLS activity suggest that the mechanisms underlying the incubation of methamphetamine craving after forced versus voluntary abstinence can be partly dissociable.

The data from our two incubation of methamphetamine craving studies on the role of DMS in relapse to drug seeking extend results from two studies demonstrating a role of DMS in alcohol seeking (Corbit and Janak, 2016; Ron and Barak, 2016). In one study, Wang et al. (2010) showed that the inhibition of NR2Bcontaining NMDA receptors or Src family protein tyrosine kinase in DMS decreases alcohol priming-induced reinstatement of al- 
cohol seeking. In another study, Corbit et al. (2012) showed that muscimol-baclofen inactivation of the DMS decreases alcohol seeking in an extinction test after short-term but not long-term alcohol self-administration training.

A main finding in our study was that the incubation-associated Fos-positive DMS neurons coexpressed both $\operatorname{Drd1}$ and $\operatorname{Drd2}$, indicating that the neuronal ensemble encoding the incubated methamphetamine seeking that we inhibited with the Daun02 procedure is not cell type specific. The present results are consistent with our previous results showing that after forced abstinence from methamphetamine, the incubation-sensitive Fos-positive neurons in both DMS and DLS coexpressed both Drd1 and Drd2 (Li et al., 2015c). The current observation that the putative DMS neuronal ensembles that mediate the incubation of methamphetamine craving is not cell type specific is consistent with those from our previous Daun02 inactivation studies showing the that the Fos-expressing neuronal ensembles in the nucleus accumbens (Cruz et al., 2014), ventral mPFC (Bossert et al., 2011; Warren et al., 2016), and orbitofrontal cortex (Fanous et al., 2012) are not cell type specific.

As can be seen in Figure 2, a small proportion of dorsal striatum Fos-positive neurons did not coexpress Drd1 or Drd2. We speculate that these activated neurons are cholinergic interneurons that comprise of $\sim 2 \%$ of dorsal striatum neurons (Graybiel, 1995). There is evidence that cholinergic interneurons are involved in associative learning and reward processing (Pisani et al., 2007), are strongly excited during movement (Benhamou et al., 2014), and their activity correlates with the phasic activity of substantia nigra pars compacta dopamine neurons (Morris et al., 2004). A question for future research is whether the Fos-positive neurons in DMS that do not coexpress dopamine receptors play a role in the incubation of methamphetamine craving.

Finally, our Daun02 inactivation results showing that the selective inactivation of a small proportion of activated DMS neurons mimics the behavioral effects of acute dopamine receptor blockade that interferes with the normal function of a much larger neuronal population provide additional support for the unique utility of this experimental procedure for studying causal roles of neuronal ensembles in learned behaviors in rats (Cruz et al., 2013).

\section{Concluding remarks}

We recently developed a choice-based rat model of drug relapse and craving after voluntary abstinence (Caprioli et al., 2015b) and proposed that our model mimics features of human relapse after the cessation of voucher-based contingency management (Higgins et al., 1991; Roll, 2007; Silverman et al., 2012). Here, we used RNAscope and pharmacological and chemogenetic methods to investigate brain mechanisms of the incubation of methamphetamine craving after voluntary abstinence. Our results show that this incubation is associated with time-dependent increases in DMS activity and that local $\mathrm{D}_{1}$ and $\mathrm{D}_{2}$ family dopamine receptors play a critical role in the incubation of methamphetamine craving. Our results also indicate that a small subset of DMS neurons form neuronal ensembles, which encode the learned associations between methamphetamine reward and cues and contexts associated with methamphetamine selfadministration, mediate the incubation of methamphetamine craving after voluntary abstinence.

\section{References}

Abdolahi A, Acosta G, Breslin FJ, Hemby SE, Lynch WJ (2010) Incubation of nicotine seeking is associated with enhanced protein kinase A-regulated signaling of dopamine- and cAMP-regulated phosphoprotein of $32 \mathrm{kDa}$ in the insular cortex. Eur J Neurosci 31:733-741. CrossRef Medline
Ahmed SH, Guillem K, Vandaele Y (2013) Sugar addiction: pushing the drug-sugar analogy to the limit. Curr Opin Clin Nutr Metab Care 16:434439. CrossRef Medline

Bakina E, Farquhar D (1999) Intensely cytotoxic anthracycline prodrugs: galactosides. Anticancer Drug Des 14:507-515. Medline

Becker JB, Koob GF (2016) Sex differences in animal models: focus on addiction. Pharmacol Rev 68:242-263. CrossRef Medline

Bedi G, Preston KL, Epstein DH, Heishman SJ, Marrone GF, Shaham Y, de Wit H (2011) Incubation of cue-induced cigarette craving during abstinence in human smokers. Biol Psychiatry 69:708-711. CrossRef Medline

Belin D, Everitt BJ (2008) Cocaine seeking habits depend upon dopaminedependent serial connectivity linking the ventral with the dorsal striatum. Neuron 57:432-441. CrossRef Medline

Belin D, Jonkman S, Dickinson A, Robbins TW, Everitt BJ (2009) Parallel and interactive learning processes within the basal ganglia: relevance for the understanding of addiction. Behav Brain Res 199:89-102. CrossRef Medline

Benhamou L, Kehat O, Cohen D (2014) Firing pattern characteristics of tonically active neurons in rat striatum: context dependent or species divergent? J Neurosci 34:2299-2304. CrossRef Medline

Bienkowski P, Rogowski A, Korkosz A, Mierzejewski P, Radwanska K, Kaczmarek L, Bogucka-Bonikowska A, Kostowski W (2004) Time-dependent changes in alcohol-seeking behaviour during abstinence. Eur Neuropsychopharmacol 14:355-360. CrossRef Medline

Bossert JM, Wihbey KA, Pickens CL, Nair SG, Shaham Y (2009) Role of dopamine $\mathrm{D}(1)$-family receptors in dorsolateral striatum in contextinduced reinstatement of heroin seeking in rats. Psychopharmacology 206:51-60. CrossRef Medline

Bossert JM, Stern AL, Theberge FR, Cifani C, Koya E, Hope BT, Shaham Y (2011) Ventral medial prefrontal cortex neuronal ensembles mediate context-induced relapse to heroin. Nat Neurosci 14:420-422. CrossRef Medline

Bossert JM, Marchant NJ, Calu DJ, Shaham Y (2013) The reinstatement model of drug relapse: recent neurobiological findings, emerging research topics, and translational research. Psychopharmacology 229:453-476. CrossRef Medline

Calu DJ, Chen YW, Kawa AB, Nair SG, Shaham Y (2014) The use of the reinstatement model to study relapse to palatable food seeking during dieting. Neuropharmacology 76:395-406. CrossRef Medline

Cantin L, Lenoir M, Augier E, Vanhille N, Dubreucq S, Serre F, Vouillac C, Ahmed SH (2010) Cocaine is low on the value ladder of rats: possible evidence for resilience to addiction. PLoS One 5:e11592. CrossRef Medline

Caprioli D, Zeric T, Thorndike EB, Venniro M (2015a) Persistent palatable food preference in rats with a history of limited and extended access to methamphetamine self-administration. Addict Biol 20:913926. CrossRef Medline

Caprioli D, Venniro M, Zeric T, Li X, Adhikary S, Madangopal R, Marchant NJ, Lucantonio F, Schoenbaum G, Bossert JM, Shaham Y (2015b) Effect of the novel positive allosteric modulator of metabotropic glutamate receptor 2 AZD8529 on incubation of methamphetamine craving after prolonged voluntary abstinence in a rat model. Biol Psychiatry 78:463-473. CrossRef Medline

Carroll ME, Lynch WJ (2016) How to study sex differences in addiction using animal models. Addict Biol 21:1007-1029. CrossRef Medline

Carroll ME, Lynch WJ, Roth ME, Morgan AD, Cosgrove KP (2004) Sex and estrogen influence drug abuse. Trends Pharmacol Sci 25:273-279. CrossRef Medline

Chipkin RE, Iorio LC, Coffin VL, McQuade RD, Berger JG, Barnett A (1988) Pharmacological profile of SCH39166: a dopamine D1 selective benzonaphthazepine with potential antipsychotic activity. J Pharmacol Exp Ther 247:1093-1102. Medline

Cifani C, Koya E, Navarre BM, Calu DJ, Baumann MH, Marchant NJ, Liu QR, Khuc T, Pickel J, Lupica CR, Shaham Y, Hope BT (2012) Medial prefrontal cortex neuronal activation and synaptic alterations after stressinduced reinstatement of palatable food seeking: a study using c-fos-GFP transgenic female rats. J Neurosci 32:8480-8490. CrossRef Medline

Corbit LH, Janak PH (2016) Habitual alcohol seeking: neural bases and possible relations to alcohol use disorders. Alcohol Clin Exp Res 40:13801389. CrossRef Medline

Corbit LH, Nie H, Janak PH (2012) Habitual alcohol seeking: time course 
and the contribution of subregions of the dorsal striatum. Biol Psychiatry 72:389-395. CrossRef Medline

Cox BM, Young AB, See RE, Reichel CM (2013) Sex differences in methamphetamine seeking in rats: impact of oxytocin. Psychoneuroendocrinology 38:2343-2353. CrossRef Medline

Cruz FC, Koya E, Guez-Barber DH, Bossert JM, Lupica CR, Shaham Y, Hope BT (2013) New technologies for examining the role of neuronal ensembles in drug addiction and fear. Nat Rev Neurosci 14:743-754. CrossRef Medline

Cruz FC, Babin KR, Leao RM, Goldart EM, Bossert JM, Shaham Y, Hope BT (2014) Role of nucleus accumbens shell neuronal ensembles in contextinduced reinstatement of cocaine-seeking. J Neurosci 34:7437-7446. CrossRef Medline

Curran T, Morgan JI (1995) Fos: an immediate-early transcription factor in neurons. J Neurobiol 26:403-412. CrossRef Medline

de Guglielmo G, Crawford E, Kim S, Vendruscolo LF, Hope BT, Brennan M, Cole M, Koob GF, George O (2016) Recruitment of a neuronal ensemble in the central nucleus of the amygdala is required for alcohol dependence. J Neurosci 36:9446-9453. CrossRef Medline

Engeln M, Bastide MF, Toulmé E, Dehay B, Bourdenx M, Doudnikoff E, Li Q, Gross CE, Boué-Grabot E, Pisani A, Bezard E, Fernagut PO (2016) Selective inactivation of striatal FosB/DeltaFosB-expressing neurons alleviates L-DOPA-induced dyskinesia. Biol Psychiatry 79:354-361. CrossRef Medline

Epstein DH, Preston KL (2003) The reinstatement model and relapse prevention: a clinical perspective. Psychopharmacology 168:31-41. CrossRef Medline

Everitt BJ, Belin D, Economidou D, Pelloux Y, Dalley JW, Robbins TW (2008) Review. Neural mechanisms underlying the vulnerability to develop compulsive drug-seeking habits and addiction. Philos Trans R Soc Lond B Biol Sci 363:3125-3135. CrossRef Medline

Fanous S, Goldart EM, Theberge FR, Bossert JM, Shaham Y, Hope BT (2012) Role of orbitofrontal cortex neuronal ensembles in the expression of incubation of heroin craving. J Neurosci 32:11600-11609. CrossRef Medline

Fuchs RA, Branham RK, See RE (2006) Different neural substrates mediate cocaine seeking after abstinence versus extinction training: a critical role for the dorsolateral caudate-putamen. J Neurosci 26:3584-3588. CrossRef Medline

Funk D, Coen K, Tamadon S, Hope BT, Shaham Y, Lê AD (2016) Role of central amygdala neuronal ensembles in incubation of nicotine craving. J Neurosci 36:8612-8623. CrossRef Medline

Ghosh AK, Khan S, Marini F, Nelson JA, Farquhar D (2000) A daunorubicin beta-galactoside prodrug for use in conjunction with gene-directed enzyme prodrug therapy. Tetrahedron Lett 41:4871-4874. CrossRef

Graybiel AM (1995) The basal ganglia. Trends Neurosci 18:60-62. CrossRef Medline

Grimm JW, Hope BT, Wise RA, Shaham Y (2001) Incubation of cocaine craving after withdrawal. Nature 412:141-142. CrossRef Medline

Higgins ST, Delaney DD, Budney AJ, Bickel WK, Hughes JR, Foerg F, Fenwick JW (1991) A behavioral approach to achieving initial cocaine abstinence. Am J Psychiatry 148:1218-1224. CrossRef Medline

Hunt WA, Barnett LW, Branch LG (1971) Relapse rates in addiction programs. J Clin Psychol 27:455-456. CrossRef Medline

Ito R, Dalley JW, Howes SR, Robbins TW, Everitt BJ (2000) Dissociation in conditioned dopamine release in the nucleus accumbens core and shell in response to cocaine cues and during cocaine-seeking behavior in rats. J Neurosci 20:7489-7495. Medline

Ito R, Dalley JW, Robbins TW, Everitt BJ (2002) Dopamine release in the dorsal striatum during cocaine-seeking behavior under the control of a drug-associated cue. J Neurosci 22:6247-6253. Medline

Jaffe JH (1990) Drug addiction and drug abuse. In: Goodman and Gilman's the pharmacological basis of therapeutics, Ed 8 (Gilman AG, Rall TW, Nies AS, Taylor P, eds), pp 522-573. New York: Pergamon.

Kasof GM, Smeyne RJ, Curran T, Morgan JI (1996) Developmental expression of Fos-lacZ in the brains of postnatal transgenic rats. Brain Res Dev Brain Res 93:191-197. CrossRef Medline

Kerstetter KA, Aguilar VR, Parrish AB, Kippin TE (2008) Protracted timedependent increases in cocaine-seeking behavior during cocaine withdrawal in female relative to male rats. Psychopharmacology 198:63-75. CrossRef Medline

Köhler C, Hall H, Ogren SO, Gawell L (1985) Specific in vitro and in vivo binding of $3 \mathrm{H}$-raclopride. A potent substituted benzamide drug with high affinity for dopamine D-2 receptors in the rat brain. Biochem Pharmacol 34:2251-2259. CrossRef Medline

Koya E, Golden SA, Harvey BK, Guez-Barber DH, Berkow A, Simmons DE, Bossert JM, Nair SG, Uejima JL, Marin MT, Mitchell TB, Farquhar D, Ghosh SC, Mattson BJ, Hope BT (2009) Targeted disruption of cocaineactivated nucleus accumbens neurons prevents context-specific sensitization. Nat Neurosci 12:1069-1073. CrossRef Medline

Krasnova IN, Marchant NJ, Ladenheim B, McCoy MT, Panlilio LV, Bossert JM, Shaham Y, Cadet JL (2014) Incubation of methamphetamine and palatable food craving after punishment-induced abstinence. Neuropsychopharmacology 39:2008-2016. CrossRef Medline

Lenoir M, Serre F, Cantin L, Ahmed SH (2007) Intense sweetness surpasses cocaine reward. PLoS One 2:e698. CrossRef Medline

Lesscher HM, Vanderschuren LJ (2012) Compulsive drug use and its neural substrates. Rev Neurosci 23:731-745. CrossRef Medline

Li X, Zeric T, Kambhampati S, Bossert JM, Shaham Y (2015a) The central amygdala nucleus is critical for incubation of methamphetamine craving. Neuropsychopharmacology 40:1297-1306. CrossRef Medline

Li P, Wu P, Xin X, Fan YL, Wang GB, Wang F, Ma MY, Xue MM, Luo YX, Yang FD, Bao YP, Shi J, Sun HQ, Lu L (2015b) Incubation of alcohol craving during abstinence in patients with alcohol dependence. Addict Biol 20:513-522. CrossRef Medline

Li X, Rubio FJ, Zeric T, Bossert JM, Kambhampati S, Cates HM, Kennedy PJ, Liu QR, Cimbro R, Hope BT, Nestler EJ, Shaham Y (2015c) Incubation of methamphetamine craving is associated with selective increases in expression of Bdnf and trkb, glutamate receptors, and epigenetic enzymes in cue-activated fos-expressing dorsal striatal neurons. J Neurosci 35:82328244. CrossRef Medline

Lu L, Grimm JW, Hope BT, Shaham Y (2004) Incubation of cocaine craving after withdrawal: a review of preclinical data. Neuropharmacology 47 [Suppl 1]:214-226. CrossRef Medline

Marlatt AG (1996) Models of relapse and relapse prevention: a commentary. Exp Clin Psychopharmacol 4:55-60. CrossRef

Momparler RL, Karon M, Siegel SE, Avila F (1976) Effect of adriamycin on DNA, RNA, and protein-synthesis in cell-free systems and intact-cells. Cancer Res 36:2891-2895. Medline

Morgan JI, Curran T (1991) Stimulus-transcription coupling in the nervous system: involvement of the inducible proto-oncogenes fos and jun. Annu Rev Neurosci 14:421-451. CrossRef Medline

Morris G, Arkadir D, Nevet A, Vaadia E, Bergman H (2004) Coincident but distinct messages of midbrain dopamine and striatal tonically active neurons. Neuron 43:133-143. CrossRef Medline

Pacchioni AM, Gabriele A, See RE (2011) Dorsal striatum mediation of cocaine-seeking after withdrawal from short or long daily access cocaine selfadministration in rats. Behav Brain Res 218:296-300. CrossRef Medline

Parvaz MA, Moeller SJ, Goldstein RZ (2016) Incubation of cue-induced craving in human cocaine addiction measured by EEG. JAMA Psychiatry 73:1127-1134. CrossRef Medline

Paxinos G, Watson C (2008) The rat brain in stereotaxic coordinates, Ed 6 . San Diego: Academic.

Pfarr S, Meinhardt MW, Klee ML, Hansson AC, Vengeliene V, Schönig K, Bartsch D, Hope BT, Spanagel R, Sommer WH (2015) Losing control: excessive alcohol seeking after selective inactivation of cue-responsive neurons in the infralimbic cortex. J Neurosci 35:10750-10761. CrossRef Medline

Pickens CL, Airavaara M, Theberge F, Fanous S, Hope BT, Shaham Y (2011) Neurobiology of the incubation of drug craving. Trends Neurosci 34:411420. CrossRef Medline

Pisani A, Bernardi G, Ding J, Surmeier DJ (2007) Re-emergence of striatal cholinergic interneurons in movement disorders. Trends Neurosci 30: 545-553. CrossRef Medline

Rawson RA, Marinelli-Casey P, Anglin MD, Dickow A, Frazier Y, Gallagher C, Galloway GP, Herrell J, Huber A, McCann MJ, Obert J, Pennell S, Reiber C, Vandersloot D, Zweben J (2004) A multi-site comparison of psychosocial approaches for the treatment of methamphetamine dependence. Addiction 99:708-717. CrossRef Medline

Roll JM (2007) Contingency management: an evidence-based component of methamphetamine use disorder treatments. Addiction 102 [Suppl 1]: 114-120. CrossRef Medline

Ron D, Barak S (2016) Molecular mechanisms underlying alcohol-drinking behaviours. Nat Rev Neurosci 17:576-591. CrossRef Medline

Rubio FJ, Liu QR, Li X, Cruz FC, Leão RM, Warren BL, Kambhampati S, 
Babin KR, McPherson KB, Cimbro R, Bossert JM, Shaham Y, Hope BT (2015) Context-induced reinstatement of methamphetamine seeking is associated with unique molecular alterations in Fos-expressing dorsolateral striatum neurons. J Neurosci 35:5625-5639. CrossRef Medline

Shalev U, Morales M, Hope B, Yap J, Shaham Y (2001) Time-dependent changes in extinction behavior and stress-induced reinstatement of drug seeking following withdrawal from heroin in rats. Psychopharmacology 156:98-107. CrossRef Medline

Silverman K, DeFulio A, Sigurdsson SO (2012) Maintenance of reinforcement to address the chronic nature of drug addiction. Prev Med 55 [Suppl]:S46-S53. CrossRef

Tran-Nguyen LT, Fuchs RA, Coffey GP, Baker DA, O’Dell LE, Neisewander JL (1998) Time-dependent changes in cocaine-seeking behavior and extracellular dopamine levels in the amygdala during cocaine withdrawal. Neuropsychopharmacology 19:48-59. CrossRef Medline

Vandaele Y, Cantin L, Serre F, Vouillac-Mendoza C, Ahmed SH (2016) Choosing under the influence: a drug-specific mechanism by which the setting controls drug choices in rats. Neuropsychopharmacology 41: 646-657. CrossRef Medline

Vanderschuren LJ, Di Ciano P, Everitt BJ (2005) Involvement of the dorsal striatum in cue-controlled cocaine seeking. J Neurosci 25:8665-8870. CrossRef Medline
Venniro M, Caprioli D, Shaham Y (2016) Animal models of drug relapse and craving: from drug priming-induced reinstatement to incubation of craving after voluntary abstinence. Prog Brain Res 224:25-52. CrossRef Medline

Venniro M, Zhang M, Palmer A, Shaham Y, Caprioli D (2017) Incubation of methamphetamine but not heroin craving after voluntary abstinence in male and female rats. Neuropsychopharmacology, in press.

Wang F, Flanagan J, Su N, Wang LC, Bui S, Nielson A, Wu X, Vo HT, Ma XJ, Luo Y (2012) RNAscope: a novel in situ RNA analysis platform for formalin-fixed, paraffin-embedded tissues. J Mol Diagn 14:22-29. CrossRef Medline

Wang G, Shi J, Chen N, Xu L, Li J, Li P, Sun Y, Lu L (2013) Effects of length of abstinence on decision-making and craving in methamphetamine abusers. PLoS One 8:e68791. CrossRef Medline

Wang J, Lanfranco MF, Gibb SL, Yowell QV, Carnicella S, Ron D (2010) Long-lasting adaptations of the NR2B-containing NMDA receptors in the dorsomedial striatum play a crucial role in alcohol consumption and relapse. J Neurosci 30:10187-10198. CrossRef Medline

Warren BL, Mendoza MP, Cruz FC, Leao RM, Caprioli D, Rubio FJ, Whitaker LR, McPherson KB, Bossert JM, Shaham Y, Hope BT (2016) Distinct Fos-expressing neuronal ensembles in the ventromedial prefrontal cortex mediate food reward and extinction memories. J Neurosci 36:6691-6703. CrossRef Medline 